\title{
Deep-water Asteroidea (Echinodermata) collected during the TALUD cruises in the Gulf of California, Mexico
}

\section{Asteroidea (Echinodermata) de aguas profundas recolectados durante cruceros TALUD en el golfo de California, México}

\author{
Michel E. Hendrickx ${ }^{1 *}$, Christopher Mah $^{2}$ and Carlo Magno Zárate-Montes ${ }^{1,3}$ \\ ${ }^{1}$ Laboratorio de Invertebrados Bentónicos, Unidad Académica Mazatlán, Instituto de Ciencias del Mar y Limnología, Universidad Nacional Autónoma \\ de México, Apartado postal 811, 82000 Mazatlán, Sinaloa, México. \\ ${ }^{2}$ Department of Invertebrate Zoology, Smithsonian Institution, Washington D.C., USA. \\ ${ }^{3}$ Posgraduate Program, Instituto de Ciencias del Mar y Limnología, Universidad Nacional Autónoma de México. Apartado postal 70-305, 04510 México, \\ D.F., México. \\ *Correspondent:michel@ola.icmyl.unam.mx
}

\begin{abstract}
During a series of cruises aboard the R/V "El Puma" aimed at collecting the deep-water benthic and pelagic fauna off the Pacific coast of Mexico, in the eastern Pacific, samples of Asteroidea were collected below $500 \mathrm{~m}$ depth (587-1 $526 \mathrm{~m})$. A total of 335 specimens were collected, belonging to 18 species, 14 identified to species, 3 to genus, and 1 previously undescribed species. New records are provided for Dipsacaster laetmophilus Fisher, 1910, Myxoderma sacculatum (Fisher, 1905), Peribolaster biserialis Fisher, 1905, Ampheraster chiroplus Fisher, 1928, Ampheraster hyperoncus (H. L. Clark, 1913), Anteliaster coscinactis Fisher, 1923, Nearchaster aciculosus (Fisher, 1910), Ceramaster leptoceramus (Fisher, 1905), Mediaster transfuga Ludwig, 1905, and Lophaster furcilliger Fisher, 1905. All species were collected below the oxygen minimum zone that extends throughout the central and southern Gulf of California, or within the threshold zone where severe to mild hypoxic conditions prevail. Epibenthic dissolved oxygen concentrations associated with the capture of the specimens show support for strong tolerance to severe hypoxia $\left(<1.0 \mathrm{ml} \mathrm{O}_{2} / 1\right)$ for most species, but only mild hypoxia for Ctenodiscus crispatus (Retzius, 1805), and Nymphaster diomedeae Ludwig, 1905. A checklist of all species of Asteroidea occurring below $500 \mathrm{~m}$ depth off the Pacific coast of Mexico is included.
\end{abstract}

Key words: Asteroidea, continental slope, western Mexico.

Resumen. Durante una serie de campañas oceanográficas realizadas a bordo del B/O "El Puma", enfocadas a la recolección de la fauna bentónica y pelágica de aguas profundas en la costa del Pacífico de México, en el Pacífico oriental, se recolectaron ejemplares de Asteroidea por debajo de $500 \mathrm{~m}$ de profundidad (587-1 $526 \mathrm{~m}$ ). Un total de 335 ejemplares fueron recolectados, pertenecientes a 18 especies; 14 fueron determinadas hasta especie, 3 hasta género y 1 especie no descrita. Se proporcionan nuevos registros para Dipsacaster laetmophilus Fisher, 1910, Myxoderma sacculatum (Fisher, 1905), Peribolaster biserialis Fisher, 1905, Ampheraster chiroplus Fisher, 1928, Ampheraster hyperoncus (H. L. Clark, 1913), Anteliaster coscinactis Fisher, 1923, Nearchaster aciculosus (Fisher, 1910), Ceramaster leptoceramus (Fisher, 1905), Mediaster transfuga Ludwig, 1905, y Lophaster furcilliger Fisher, 1905. Todas las especies se recolectaron por debajo de la zona del mínimo de oxígeno que se extiende por las zonas central y sur del golfo de California, o en el umbral de la zona donde prevalecen condiciones de hipoxia de leves a severas. Las concentraciones de oxígeno disuelto epibentónicas asociadas con la captura de los ejemplares indican una fuerte tolerancia a la hipoxia severa $\left(<1,0 \mathrm{ml} \mathrm{O}_{2} / 1\right)$ para la mayoría de las especies, y a hipoxia leve para Ctenodiscus crispatus (Retzius, 1805) y Nymphaster diomedeae Ludwig, 1905. Se incluye una lista de todas las especies de asteroideos que se encuentran por debajo de $500 \mathrm{~m}$ de profundidad frente a la costa del Pacífico de México.

Palabras clave: Asteroidea, talud continental, Pacífico este, México.

\section{Introduction}

Deep-sea macroinvertebrates communities are characterized by high diversity values (see Grassle, 1989;

Recibido: 10 junio 2010; aceptado: 14 octubre 2010
Smith et al., 1998). In areas where the oxygen-minimum zone (OMZ) intercepts the continental slope, anoxic and severely hypoxic benthic fringes are species-poor. This is in contrast to the hypoxic zone extending into even deeper water, which is species-rich. In the OMZ, depth and dissolved oxygen concentration are the most important factors affecting the composition and species size of deep- 
water communities (Levin and Gage, 1998; Rogers, 2000; Hendrickx, 2001; Levin et al., 2001; McClain and Rex, 2001; McClain, 2004; Méndez, 2006; Zamorano et al., 2006).

Environmental conditions occurring on the deepsea benthos (i.e., muddy sediments, abundant detritus as food source, stable values of salinity and temperature) favor settlement and dominance of infauna and epifauna communities which are often highly diverse (Rex et al., 2000; Borowski, 2001; Levin et al., 2001; Reynolds, 2002; Kröncke and Türkay, 2003; Méndez, 2006; Tilot, 2006). As a generality, deep-water crustaceans, echinoderms and fish are better represented in benthic samples obtained from sledges or beam-trawls than in box cores. Due to difficulties that stem from operating in deep water, therefore a general lack of information exists related to their distribution, abundance and community composition.

Deep-water echinoderms have been scantily studied in the East Pacific south of the California Current area. The Asteroidea collected from the deep-water HMS "Challenger" expeditions, off the Galapagos Islands and Panama, were studied by Sladen $(1883,1889)$ who described 6 deep-water species. The second major deepwater sampling program off the Pacific coast of America took place at the end of the 19th and beginning of the 20th centuries (1892-1911), when the USFC "Albatross" surveyed the west coast of the Americas, from Peru to California, including Mexico, and collected many specimens during trawling operations in deep water. The "Albatross" Asteroidea collections were described by Ludwig (1905, 1907) and H. L. Clark (1913, 1920, 1923). Northeast Pacific asteroids were monographed by Walter $\mathrm{K}$. Fisher in a long series of contributions published from 1905 to 1940 (e.g., Fisher, 1905, 1906a, 1906b, 1910a, 1910b, 1917, 1928a, 1928b).

Maluf (1988) indicated that 109 species of Asteroidea occurred below $500 \mathrm{~m}$ depth in the central eastern Pacific. Some of these species, however, occurred on the continental shelf in relatively shallow water and were only occasionally present at depths greater then $500 \mathrm{~m}$ (i.e., Luidia asthenosoma, 20-620 m; Odontaster crassus, 27-595 m; Henricia aspera, 18-572 m; Stylasterias forreri, 29-532 m). Most of these 109 species were described based on material collected from the eastern Pacific in the early to mid $20^{\text {th }}$ Century and were monographed by Ludwig (1905; 1907: 39 species described), Fisher (1905, 1906a, 1906b, 1910a, 1910b, 1917, 1928 a, b: 44 species described), and H. L. Clark (1913, 1920: 8 species described).

Maluf (1988) showed that 52 of these 109 species had at least 1 record off the western coast of Mexico. Subsequent accounts summarizing the distribution of species of Asteroidea occurring off the Pacific coast of Mexico include Maluf (1991), Nybakken et al. (1998), Solís-Marín et al. (2005), Maluf and Brusca (2005), Keller et al. (2007), and Honey-Escandón et al. (2008). Alton (1966) reported 54 species of bathyal and abyssal sea stars from northern Oregon. Carey (1972) summarized distributions of sublittoral to abyssal asteroids from the Northeast Pacific Ocean and listed their feeding type and food sources. Mah (2007) reviewed the Zoroasteridae, providing new data for zoroasterid species occurring off western Mexico and nearby areas.

Because very few sampling efforts in deep water of the East Pacific have been undertaken by Mexican institutions, a major exploring project aimed at studying the invertebrate and fish communities associated with the continental slope (the TALUD project) was designed. The aim of this project was to increase or knowledge of the bathyal fauna and to estimate species diversity in Mexican waters.

\section{Materials and methods}

Samples of Asteroidea were obtained from depths of 587-1 $525 \mathrm{~m}$ on the continental slope along the Pacific coast of Mexico using an Agassiz dredge and a benthic sledge ( $2.5 \mathrm{~m}$ width, $0.9 \mathrm{~m}$ high) equipped with a modified shrimp net (ca $5.5 \mathrm{~cm}$ stretched mesh size) with a ca $2.0 \mathrm{~cm}(3 / 4$ ") internal lining net. A total of 13 cruises were organized in the Gulf of California from 1989 to 2008. Specimens of Asteroidea were collected during the following cruises: TALUD III, 17-24 August 1991; TALUD IV, 23-27 August 2000; TALUD V, 13-18 December 2000; TALUD VI, 13-17 March 2001; TALUD VII, 5-9 June 2001; TALUD VIII, 16-23 April; TALUD IX, 10-15 November 2005; and TALUD X, 9-15 February 2007. During these cruises, a total of 117 localities were sampled, from 377 to $2394 \mathrm{~m}$ depth, and Asteroidea were captured in 25 of these. Positional coordinates for each sampling station were plotted using a GPS navigation system. Depth was measured with an EdoWestern, analogic recorder (TALUD III-VIII) or a digital recorder (TALUD IX-X). Epibenthic water temperature and salinity were measured with a Seabird CTD, and dissolved oxygen content was estimated with the Winkler method (all cruises) and with a probe attached to the CTD (TALUD VIII-X). Specimens were fixed on board with a $4 \%$ formalin sea water solution for a short period (usually a few days), washed with tap water and preserved in $70 \%$ ethanol. Density of abundant species was evaluated using the swept area method considering an average sampling speed of 1.75 knots, the trawling time (30 minutes in most cases), and the width of the gear-mouth $(2.5 \mathrm{~m})$. 
In the systematic section below, primary synonyms and other significant references are included for each species. References to Mexican material are all included, together with comments and additional data related to the distribution and ecology of each species. The material collected during this survey is deposited in the Regional Collection of Marine Invertebrates (EMU), in Mazatlán, Mexico. Duplicates of several species were also deposited in the Echinoderms Collection M. E. Caso Muñoz, ICML, UNAM, in México D.F., Mexico, and in the Smithsonian Institution collection (USNM), in Washington D.C., USA.
Based primarily on Maluf (1988), a list of all species with at least 1 record within Mexican waters of the Pacific Ocean was established (Table 1). Records following 1988 were recovered from the literature or based on the material collected during the TALUD cruises and are incorporated herein. Classification of Asteroidea adopted herein follows Clark and Downey (1992). To establish synonymies, original literature dealing with descriptions and records of deep-water Asteroidea in the East Pacific was consulted, in addition to important reviews by A. M. Clark $(1989,1993$, 1996) and A. M. Clark and Mah (2001). Other sources are indicated in the text where appropriate.

Table 1. Species of deep-water Asteroidea (> $500 \mathrm{~m}$ depth) occurring off the coast of Mexico (northernmost limit set at $32^{\circ} 28^{\prime} 16^{\prime \prime} \mathrm{N}$; southernmost limit set at 14'32'27'N), including the California Current area (CC), the Gulf of California (GC), the area of souwestern Mexico, south of Banderas Bay (SWM), and the offshore islands (OI). Data used in the table was taken from the following sources: TL, type locality MA, Maluf (1988); MA2, Maluf (1991) (only those data complementary to Maluf, 1988); SO, Solís-Marín et al. (2005); MB, Maluf and Brusca (2005); MC, Mah (2007); HE, Honey-Escandón et al. (2008); PS, present study. Bold face: species collected during the TALUD cruises. (?) Dubious record or identification; Rev., Revillagigedo Islands. For convenience, the sequence of species follows Maluf (1988)

\begin{tabular}{|c|c|c|c|c|}
\hline Species & $C C$ & $G C$ & $S W M$ & $O I$ \\
\hline Luidia asthenosoma Fisher, 1906 & MA & & & \\
\hline Luidia foliolata Grube, 1865 (1) & MA & MA & MA & \\
\hline Dipsacaster laetmophilus Fisher, 1910 & & PS & & \\
\hline Dytaster gilberti Fisher, 1905 & MA MA2 & & & \\
\hline Leptychaster inermis (Ludwig, 1905) & MA & & & \\
\hline Psilaster armatus Ludwig, 1905 & & MA MB & & \\
\hline Psilaster pectinatus (Fisher, 1905) & MA & & & \\
\hline Thrissacanthias penicillatus (Fisher, 1905) & & MA MB PS & & \\
\hline Eremicaster crassus gracilis (Salden, 1883) (2) & MA HE & MA MB & MA & \\
\hline Eremicaster pacificus (Ludwig, 1905) & MA HE & MA MB SO PS & MA & \\
\hline Hyphalaster inermis Sladen, 1883 (3) & MA & & & \\
\hline Ctenodiscus crispatus (Retzius, 1805) & MA HE & MA MB SO PS & & \\
\hline Benthopecten acanthonotus Fisher, 1905 & MA & MA MB & & \\
\hline Benthopecten pectinifer (Ludwig, 1905) & & MA MB SO & & \\
\hline Nearchaster aciculosus (Fisher, 1910) & MA & PS & & MA (Clarion) \\
\hline Pectinaster agassizii (Ludwig, 1905) (4) & MA & MA MB SO PS & & \\
\hline Odontaster crassus Fisher, 1905 & MA & MA MB & & \\
\hline Radiaster sp. nov. & & PS & & \\
\hline Ceramaster leptoceramus (Fisher, 1905) & MA & PS & MA & \\
\hline Ceramaster grenadensis patagonicus Sladen, 1889 & & MA MB & & \\
\hline Cryptopeltaster lepidonotus Fisher, 1905 & & MA MB & & \\
\hline Mediaster tenellus Fisher, 1905 & & & MA & \\
\hline Mediaster transfuga Ludwig, 1905 (5) & & PS & $\mathrm{TL}$ & \\
\hline Nymphaster diomedeae Ludwig, 1905 & & MA MB PS & & \\
\hline Pseudarchaster pectinifer Ludwig, 1905 & MA & MA MB & & \\
\hline Pseudarchaster pulcher Ludwig, 1905 & & & MA & \\
\hline Pseudarchaster pusillus Fisher, 1905 & MA & MA MB & & \\
\hline Anthenea mexicana A.H. Clark, 1916 (6) & $?$ & $?$ & $?$ & \\
\hline Lophaster furcilliger Fisher, 1905 (7) & MA & PS & & \\
\hline Lophaster validus (Ludwig, 1905) (7) & & MA MB & & \\
\hline Peribolaster biserialis Fisher, 1905. & & PS & & \\
\hline Pythonaster pacificus Downey, 1979 & MA & & & \\
\hline
\end{tabular}


Table 1. Continues

\begin{tabular}{|c|c|c|c|c|}
\hline Species & $C C$ & $G C$ & $S W M$ & $O I$ \\
\hline Hymenaster pellucidus W. Thomson, 1873 & MA & & & \\
\hline Hymenaster quadrispinosus Fisher, 1905 & MA & & & \\
\hline Hymenaster violaceus Ludwig, 1905 & & & MA & \\
\hline Pteraster jordani Fisher, 1905 & MA & & & \\
\hline Poraniopsis inflatus Fisher, 1906 & MA & & & \\
\hline Henricia aspera Fisher, 1906 & MA & MA? MB & & \\
\hline Henricia asthenactis Fisher, 1905 & & MA MB & & \\
\hline Henricia clarki Fisher, 1910 & $\mathrm{HE}$ & MA MB SO & & MA HE (Rev) \\
\hline Henricia gracilis (Ludwig, 1905) & & MA MB & & \\
\hline Henricia polyacantha Fisher, 1906 & MA & MA MB & & \\
\hline Henricia seminuda (A.H. Clark, 1906) & & & & MA HE (Rev) \\
\hline Henricia sp. 1 & & PS & & \\
\hline ? Henricia sp. 2 & & PS & & \\
\hline Cnemidiaster nudus (Ludwig, 1905) & MA & $\begin{array}{l}\text { MA MB SO } \\
\text { MC }\end{array}$ & & \\
\hline Myxoderma platyacanthum (H.L. Clark, 1913) & MA MC & SO PS & & \\
\hline Myxoderma sacculatum (Fisher, 1905) & MA & PS & & \\
\hline Myxoderma longispinum (Ludwig, 1905) (8) & & MA MB SO & & \\
\hline Myxoderma qawashqari (Moyana \& Larrain Prat, & & $\begin{array}{l}\mathrm{MC} \\
\mathrm{MC}\end{array}$ & & \\
\hline Sagenaster evermanni (Fisher, 1905) (9) & & MA MB & & \\
\hline Zoroaster actinocles Fisher, 1919 & $\mathrm{MC}$ & & & \\
\hline Zoroaster hirsutus Ludwig, 1905 & $\mathrm{MC}$ & SR & MA MC & \\
\hline Zoroaster ophiurus Fisher, 1905 & MA MC & & & \\
\hline Ampheraster chiroplus Fisher, 1928 & & PS & & \\
\hline Ampheraster hyperoncus (H.L. Clark, 1913) & MA & PS & & \\
\hline Ampheraster marianus (Ludwig, 1905) & & MA MB MC & & \\
\hline Anteliaster coscinactis Fisher, 1923 & MA & PS & & \\
\hline Rathbunaster californicus Fisher, 1906 & $\mathrm{HE}$ & MA? SO & & \\
\hline Astrolirus panamensis (Ludwig, 1905) & MA & MA MB & & \\
\hline
\end{tabular}

(1) To $476 \mathrm{~m}$ depth.

(2) Cited as Eremicaster crassus by Maluf and Brusca (2005) and Honey-Escandon et al. (2008).

(3) Unconfirmed record. See Maluf (1988:116) for details.

(4) Cited as Cheiraster agassizii by Solís-Marín et al. (2005).

(5) Included in the synonymy of M. tenellus by Maluf (1988).

(6) Unknown locality off Mexico.

(7) The status of these species and of L. furcifer (Duben and Koren, 1846) needs to be reviewed.

(8) Cited as Zoroaster longispinus (Maluf, 1988; Maluf and Brusca, 2005).

(9) Cited by Maluf (1988) as Zoroaster evermanni.

\section{Results}

A total of 335 specimens were collected during the survey, belonging to 18 species in 17 genera in 9 families. This collection is among the largest for the west coast of Mexico since the "Albatross" made her exploratory survey in the region.

Order Paxillosida

Family Astropectinidae

Dipsacaster laetmophilus Fisher, 1910
Fig. 1A, B

Dipsacaster laetmophilus Fisher, 1910b: 546 (key), 547; Fisher, 1911b: 86 (key), 95, pl. 12, fig. 3, pl. 15, figs. 1, 2, pl. 52, figs. 3, 3a, 3b, pl. 53, fig. 2.

\section{Taxonomic summary}

Material examined. TALUD III, St. 14A (243' $48^{\prime \prime}$, 108²6'54”W), 19/August/1991, two specimens ( $\mathrm{R}=58.1$ - 
$66.6 \mathrm{~mm}, \mathrm{r}=19.0-22.7 \mathrm{~mm})$, Agassiz dredge, 1016-1020 m (EMU-8963).

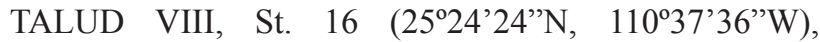
18/April/2005, two specimens $(\mathrm{R}=13.9-25.9 \mathrm{~mm}$, $\mathrm{r}=6.7-11.6 \mathrm{~mm}$ ), bottom sledge, $1030 \mathrm{~m}$ (EMU-8964).

TALUD X, St. $10\left(27^{\circ} 50^{\prime} 06^{\prime \prime} \mathrm{N}, 112^{\circ} 10^{\prime} 06^{\prime} \mathrm{W}\right)$, one specimen $(\mathrm{R}=97.1 \mathrm{~mm}, \mathrm{r}=31.4 \mathrm{~mm}), 10 / \mathrm{Feb} / 2007$, bottom sledge, 1399-1422 m (EMU-8962) (Fig. 2 A).

Previous records in Mexico. None.

Distribution and ecology. According to Fisher (1911b), this species was known only from the type locality, between Unalaska and Kodiak, USA, in depth of $1272 \mathrm{~m}(695$ fms.). Carey (1972) reported a closely related species, $D$. anoplus, as omnivorous, feeding on bivalves, gastropods, ophiuroids, crustaceans, polychaetes and some sediment. The material collected during this study (in depths of 1 030-1 $422 \mathrm{~m}$ ) was obtained within the known depth range of this species. Epibenthic temperature and dissolved oxygen concentration: $3.19-5.00^{\circ} \mathrm{C}$ and $0.20-0.44 \mathrm{ml} \mathrm{O}_{2} / 1$ (this study).
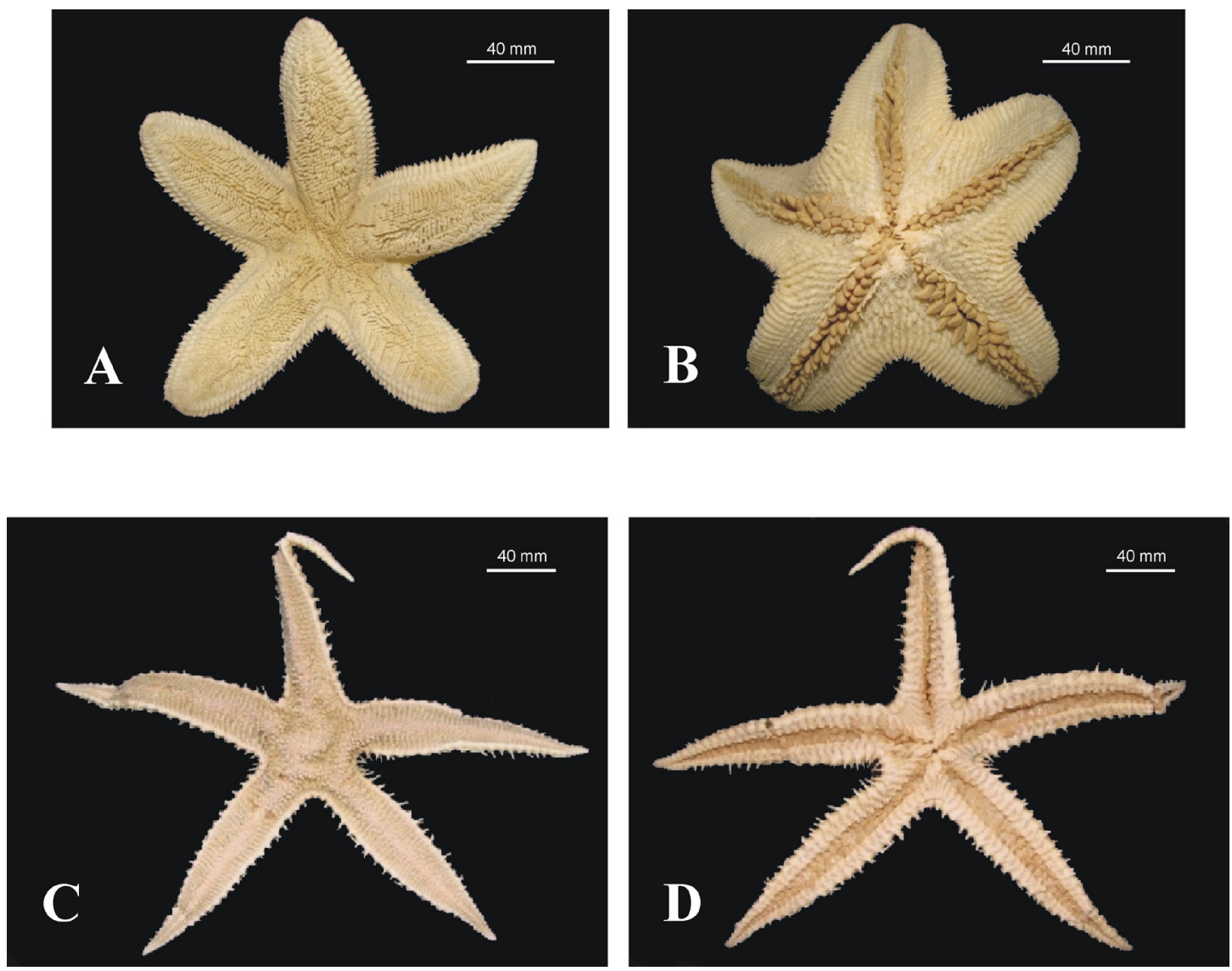

Figure 1. Paxillosida. A. Dipsacaster laetmophilus Fisher, 1910, aboral view. B. Same, oral view. C. Thrissacanthias penicillatus (Fisher, 1905), aboral view. D. Same, oral view. 
1e; 1930: 190 (list).- H. L. Clark, 1913: 190; 1923: 149.Ziesenhenne, 1937: 212.- Alton, 1966: 1696.- Blake, 1973: 45.- Muscat, 1980: 264.- Luke, 1982: 9.- Maluf, 1988: 30 (table), 116 (list).- Maluf and Brusca, 2005: 329 (list).

\section{Taxonomic summary}

Material examined. TALUD III, St. 14A $\left(24^{\circ} 38^{\prime} 48^{\prime \prime} \mathrm{N}\right.$, $\left.108^{\circ} 26^{\prime} 54^{\prime \prime} \mathrm{W}\right), \quad 19 /$ August/1991, one specimen $(\mathrm{R}=109.9 \mathrm{~mm}, \mathrm{r}=26.2 \mathrm{~mm})$, Agassiz dredge, 1016-1020 m (EMU-8965).

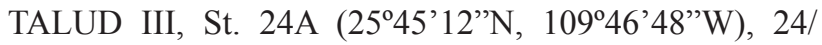
August/1991, one specimen $(\mathrm{R}=108.1 \mathrm{~mm}, \mathrm{r}=17.9 \mathrm{~mm})$, Agassiz dredge, 1027-1060 m (EMU-8966).

TALUD V, St. $19\left(24^{\circ} 16^{\prime} \mathrm{N}, 108^{\circ} 24 \mathrm{~W}\right), 15 /$ December/2000, one specimen $(\mathrm{R}=94.7 \mathrm{~mm}, \mathrm{r}=17.8 \mathrm{~mm})$, bottom sledge, 1180-1200 m (EMU-8967).

TALUD VIII, St. 3 (2431'42”N, 109²9'36”W), 16/ April $/ 2005$, one specimen $(\mathrm{R}=2.9 \mathrm{~mm} ; \mathrm{r}=1.4 \mathrm{~mm})$, bottom sledge, $1100 \mathrm{~m}$ (EMU-8968).

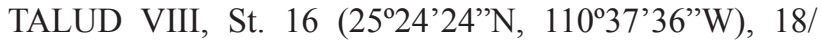
April/2005, three specimens $(\mathrm{R}=11.2-12.8 \mathrm{~mm} ; \mathrm{r}=3.5-3.6$ $\mathrm{mm}$ ), bottom sledge, $1030 \mathrm{~m}$ (EMU-8969A, B).

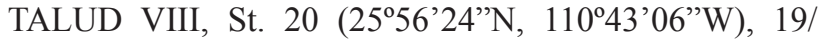
April/2005, one specimen $(\mathrm{R}=6.4 \mathrm{~mm}, \mathrm{r}=2.5 \mathrm{~mm})$, bottom sledge, $1150 \mathrm{~m}$ (EMU-8970) (Fig. 2A).

Previous records in Mexico. Type locality, "Albatross" St.
4380 (32²6'00”N, $117^{\circ} 18^{\prime} 00^{\prime}$ 'W), off Los Coronados Islands, in depths of 970-1168 m (530-638 fms.). Santa Inés Bay, east coast of the Baja California Peninsula (Ziesenhenne, 1937). Off San Pedro Island $\left(27^{\circ} 40^{\prime} \mathrm{N}\right.$, $111^{\circ} 22^{\prime} 36^{\prime}$ 'W), 931-952 m depth (Luke, 1982) (Fig. 2A).

Distribution and ecology. From Washington, USA, to Santa Inés Bay, Gulf of California, Mexico. From 55-1 $503 \mathrm{~m}$ (Maluf, 1988). Present records are from both coasts of the southern Gulf of California, thus confirming the presence of this species in the area. The material collected during this study (in depths of 1 016-1 200 m) was obtained within the known depth range of this species. Carey (1972) identified this species as a predator following the recognition of bivalves, gastropods, echinoids, ophiuroids, crustaceans, and scaphopods from gut contents. Epibenthic temperature and dissolved oxygen concentration: $5.0^{\circ} \mathrm{C}$ $\left(41.1^{\circ} \mathrm{F}\right)$ ("Albatross" St. 4380$) ; 3.00-5.00^{\circ} \mathrm{C}$ and 0.20 $0.40 \mathrm{ml} \mathrm{O}_{2} / 1$ (this study).

\section{Remarks}

H. L. Clark (1913) provided several records of $T$. penicillatus for California ("Albatross" stations), at depths of 805-1 $206 \mathrm{~m}$ (440-659 fms.) and epibenthic temperatures of $3.27-4.38{ }^{\circ} \mathrm{C}\left(37.9-39.9^{\circ} \mathrm{F}\right)$. The record of Ziesenhenne (1937) for Santa Inés Bay corresponds to young specimens taken in depth of 55-64 m (30-35 fms.),

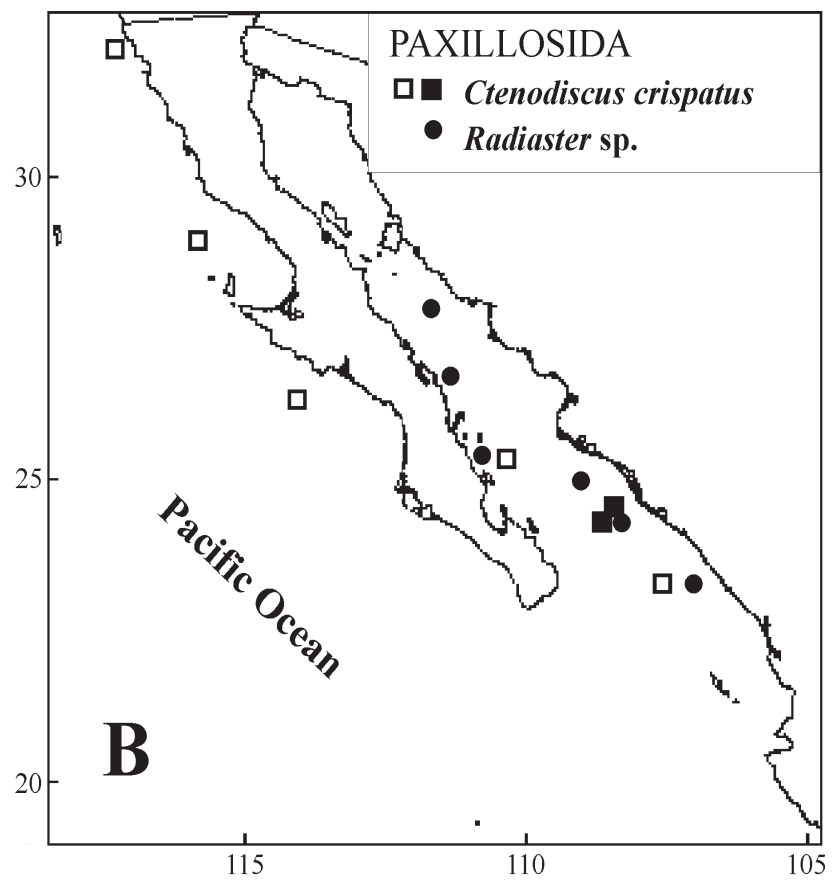

Figure 2. Distribution of examined species of Paxillosida off the Pacific coast of Mexico, including previous records (open symbols) and localities where material was collected during the TALUD survey (solid symbols). 
and represents the upper bathymetric limit reported by Maluf (1988) for this species. All other records available for T. penicillatus are in much deeper water. The Santa Inés area was sampled extensively in 1982 and 1985, at depths between 23-101 m (see Hendrickx and Salgado-Barragán, 1991) and this species was never collected in this region. Furthermore, the presence of an OMZ at water deeper than $100-150 \mathrm{~m}$ in this area represents a distributional barrier between the continental shelf and the upper slope fauna (see Hendrickx and Serrano, 2010). It seems therefore reasonable to consider this Santa Inés, shallow-water record as erroneous.

Family Ctenodiscidae

Ctenodiscus crispatus (Retzius, 1805)

Fig. 3A, B

Asterias crispatus Retzius, 1805: 17.

Ctenodiscus krauseri Ludwig, 1905: 293 (Bering Sea).

Ctenodiscus procurator Sladen, 1889: 173, 174, pl. XXX, figs. 7-12 (between 45 and $53^{\circ} \mathrm{S}$, W South America).Madsen, 1956: 16.

Ctenodiscus crispatus.- Ludwig, 1905: 104, pl. VI, figs. 32, 33.- Fisher, 1911b: 31, pl. 3, figs. 1-4, pl. 4, figs. 1-6; 1930: 188 (list).- H. L. Clark, 1913: 188; 1920: 78.- Alton, 1966: 1695.- Luke, 1982: 10.- Maluf, 1988: 32 (table), 117 (list).- Maluf and Brusca, 2005: 329.- Solís-Marín et al., 2005: 125.- Honey-Escandón et al., 2008: 60.

\section{Taxonomic summary}

Material examined. TALUD IV, St. 21 (24\%29'06”N, 108 $\left.56^{\prime} 12^{\prime \prime} \mathrm{W}\right), 25 /$ August/2000, one specimen $(\mathrm{R}=$ $37.0 \mathrm{~mm}, \mathrm{r}=13.9 \mathrm{~mm}$ ), bottom sledge, $2170-2320 \mathrm{~m}$ (EMU-8979).

TALUD V, St. $20 \quad\left(24^{\circ} 14^{\prime} 42^{\prime}\right.$ N, $\left.108^{\circ} 35^{\prime} 18^{\prime \prime} \mathrm{W}\right), 15 /$ December $/ 2000$, one specimen $(\mathrm{R}=20.5 \mathrm{~mm}, \mathrm{r}=9.7 \mathrm{~mm})$, bottom sledge, 1470-1525 m (EMU-8980) (Fig. 2 B).

Previous records in Mexico. “Albatross" St. $3430\left(23^{\circ} 16^{\prime} \mathrm{N}\right.$, $107^{\circ} 31^{\prime} \mathrm{W}$ ), Gulf of California, $1558 \mathrm{~m}$ (Ludwig, 1905).

“Albatross" St. 5686, off Ballenas Bay $\left(26^{\circ} 14^{\prime} \mathrm{N}, 114^{\circ} \mathrm{W}\right)$, 1680 m (930 fms.) (H. L. Clark, 1913). Off Descanso Bay (32 05'12'N , $\left.1171^{\prime}{ }^{\prime} \mathrm{W}\right)$ and off $\mathrm{N}$ of Cedros Island (28 55'18'N, 115 45'54”W), Baja California; Gulf of California (25 18'N, $\left.11019^{\prime} 30^{\prime \prime} \mathrm{W}\right)$; in depths of 12441908 m (Luke, 1982). Records by Solís-Marín et al. (2005) and Honey-Escandón et al. (2008) correspond to material collected by the "Albatross" (Solís-Marín, pers. comm.) (Fig. 2 B).

Distribution and ecology. Bering Sea, Alaska, USA, to Punta Mariato (Coiba), Panama; Arctic, Japan, North Atlantic, in depths of 73-2 $423 \mathrm{~m}$ (Maluf, 1988; Maluf and Brusca, 2005) and 10-1 $890 \mathrm{~m}$ (A. M. Clark, 1989). C. crispatus is an abundant infaunal species, which non-selectively feeds on organic rich sediment and occurs on muddy bottoms (see Shick et al., 1981; Carey, 1972). Epibenthic temperature and dissolved oxygen concentration: $3.28^{\circ} \mathrm{C}$ (Ludwig, 1905); $2.94^{\circ} \mathrm{C}\left(37.3^{\circ} \mathrm{F}\right)(\mathrm{H}$. L. Clark, 1913$) ; 2.40-2.80^{\circ} \mathrm{C}$ and $1.20-$ $1.82 \mathrm{ml} \mathrm{O}_{2} / 1$ (this study).

\section{Remarks}

Classification of C. crispatus follows the classification of Blake (1987) who separated Ctenodiscus from the Goniopectinidae. The material of the "Albatross" examined and reported by Ludwig (1905) is from the Gulf of Panama and the Gulf of California (young specimens). Ctenodiscus occurs widely around the world, with 2 other similar species, C. procurator and C. australis occurring in the South Atlantic and Magellanic regions.

Family Radiasteridae

Radiaster sp.

Fig. 3C, D

\section{Taxonomic summary}

Material examined. TALUD IV, St. $25\left(24^{\circ} 53^{\prime} 12^{\prime}\right.$ N, $\left.108^{\circ} 59^{\prime} 24^{\prime \prime} \mathrm{W}\right), \quad 26 /$ August $/ 2000$, three specimens $(\mathrm{R}=22.0-32.1 \mathrm{~mm}, \mathrm{r}=7.1-11.0 \mathrm{~mm})$, benthic sledge, 835 $870 \mathrm{~m}$ (EMU-8957).

TALUDV, St. $11\left(23^{\circ} 15^{\prime} \mathrm{N}, 106^{\circ} 59^{\prime} \mathrm{W}\right), 18 /$ December/2000, two specimens $(\mathrm{R}=27.9-30.1 \mathrm{~mm}, \mathrm{r}=9.1-9.3 \mathrm{~mm})$, benthic sledge, $860 \mathrm{~m}$ (EMU-8956).

TALUD VI, St. 18 (24\% $\left.14^{\prime} 54^{\prime \prime} N, 108^{\circ} 16^{\prime} 12^{\prime \prime} \mathrm{W}\right), 15 /$ March/2001, five specimens ( $\mathrm{R}=27.1-32.9 \mathrm{~mm}, \mathrm{r}=8.5-9.8$ $\mathrm{mm}$ ), benthic sledge, 890-950 m (EMU-8959).

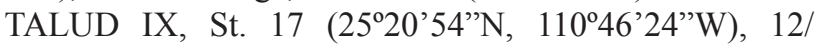
November/2005, 41 specimens $(\mathrm{R}=7.8-30.9 \mathrm{~mm}$, $\mathrm{r}=3.36-10.74 \mathrm{~mm})($ EMU-8956A, B), and three specimens $(\mathrm{R}=22.3-25.0 \mathrm{~mm} ; \mathrm{r}=7.2-8.1 \mathrm{~mm})(\mathrm{USNM}-1146557 / 567)$, benthic sledge, 826-846 m.

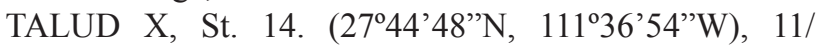
February/2007, 53 specimens $(\mathrm{R}=5.3-31.2 \mathrm{~mm}, \mathrm{r}=\mathrm{xx} \mathrm{mm})$ (EMU-8961A, B), and three specimens $(\mathrm{R}=25.3-29.6 \mathrm{~mm}$, $\mathrm{r}=9.1-10.3 \mathrm{~mm})(\mathrm{USNM}-1146564 / 558)$, benthic sledge, 905-943 m.

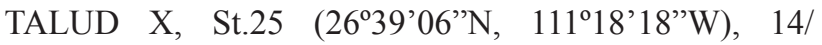
February/2007, six specimens $(\mathrm{R}=9.4-18.9 \mathrm{~mm}, \mathrm{r}=3.5-6.7$ $\mathrm{mm}$ ), benthic sledge, 837-840 m (EMU-8960) (Fig. 2B).

Previous records in Mexico. None for this genus. Not reported for the central eastern Pacific by Maluf (1988) or by subsequent authors.

Distribution and ecology. Widely distributed off the east coast of the Gulf of California, roughly from $23^{\circ} 15^{\prime} \mathrm{N}$ 

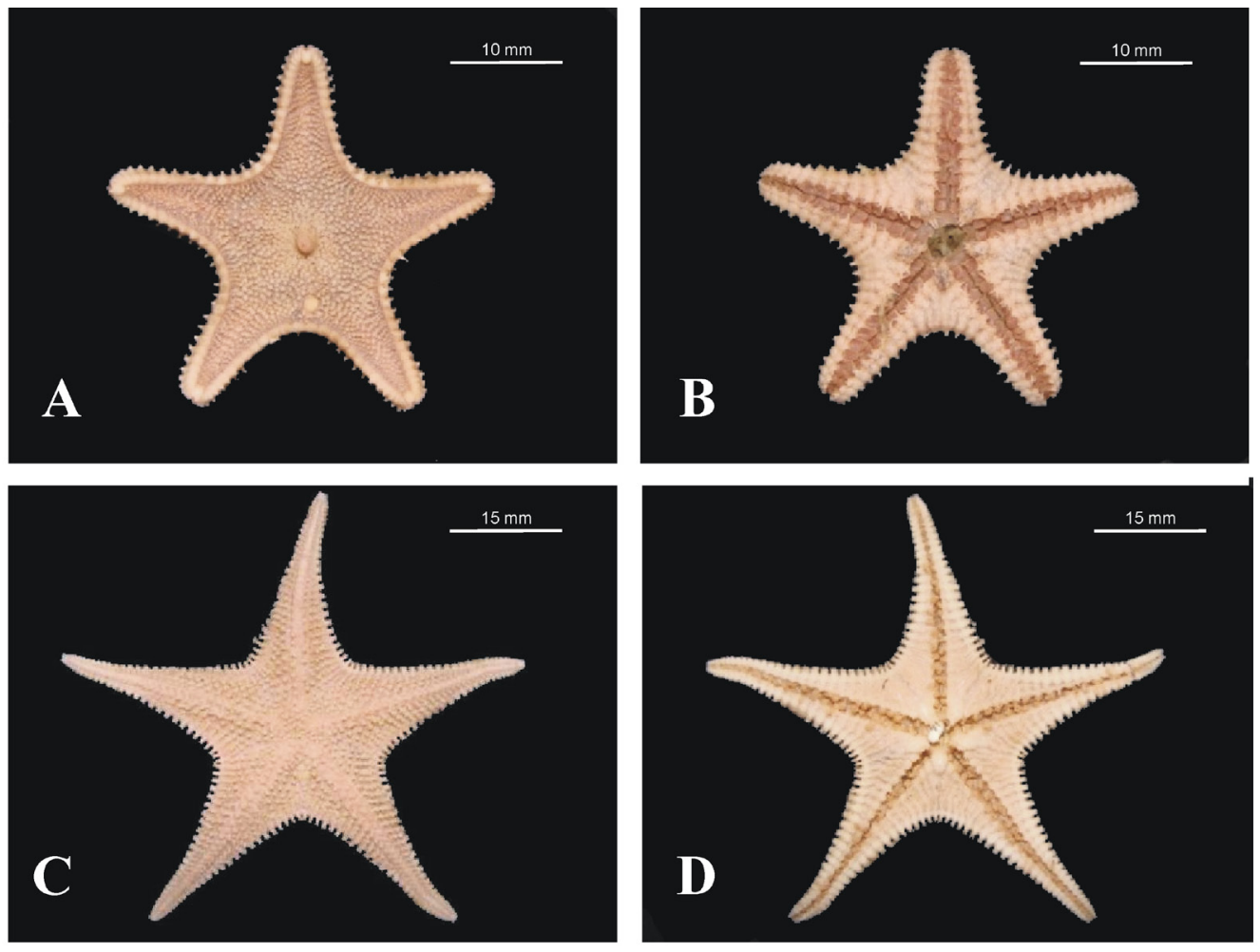

Figure 3. Paxillosida. A. Ctenodiscus crispatus (Retzius, 1805), aboral view. B. Same, oral view. C. Radiaster sp. nov., aboral view. D. Same, oral view.

(off Mazatlán) to $27^{\circ} 45^{`} \mathrm{~N}$ (off Guaymas). The material collected during this study is from depths of 826$950 \mathrm{~m}$. Epibenthic temperature and dissolved oxygen concentration: $4.64-5.40^{\circ} \mathrm{C}$ and $0.07-0.29 \mathrm{ml} \mathrm{O} / 1$.

\section{Remarks}

The specimens of Radiaster reported belong to a new species that will be described in a forthcoming paper when a comprehensive revision of material belonging to other species of this genus is completed.

Order Notomyotida

Family Benthopectinidae

Nearchaster aciculosus (Fisher, 1910)

Fig. 4A, B

Acantharchaster aciculosus Fisher, 1910b: 549 (key), 550 .

Saraster insignis A. H. Clark, 1916: 54.

Nearchaster aciculosus .- Fisher, 1911a: 91 (A. aciculosus, type species of the genus), 92, figs. 1, 3, 5; 1911b: 133, pl. 24, fig. 1, pl. 26, figs. 1-3, pl. 55, figs. 1, 1a, 1b, pl. 56, fig. 3, pl. 118, fig. 3; 1930: 191 (list).- H. L. Clark, 1913: 191.- Alton, 1966: 1699.- Muscat, 1980: 264.- Luke,
1982: 12.- Maluf, 1988: 33 (table), 117 (list).

\section{Taxonomic summary}

Material examined. TALUD V, St. $19\left(24^{\circ} 16^{\prime} 24^{\prime \prime} \mathrm{N}\right.$, $\left.108^{\circ} 24^{\prime} 18^{\prime \prime} \mathrm{W}\right), 15 /$ December/2000, five specimens $(\mathrm{R}=$ 41.9-58.5 mm, r= 5.3-7.3 mm), bottom sledge, 1180-1200 m (EMU-8996A, B).

TALUD V, St. 25 (2451'42”N, 108 $57^{\circ} 54^{\prime}$ 'W), 16/ December $/ 2000$, one specimen $(\mathrm{R}=46.6 \mathrm{~mm}, \mathrm{r}=5.8 \mathrm{~mm})$, bottom sledge, 800-860 m (EMU-8997).

TALUD IX, St. $17\left(25^{\circ} 20^{\prime} 54^{\prime \prime} \mathrm{N}, 110^{\circ} 46^{\prime} 24^{\prime \prime} \mathrm{W}\right), 13 /$ November/2005, 14 specimens $(\mathrm{R}=9.7-48.9 \mathrm{~mm}, \mathrm{r}=1.7$ $4.9 \mathrm{~mm}$ ), bottom dredge, 826-846 m (EMU-8998).

TALUD X, St. 10 (27 $\left.50^{\circ} 06^{\prime \prime N}, 112^{\circ} 10^{\prime} 06^{\prime} \mathrm{W}\right), 10 /$ February/2007, six specimens $(\mathrm{R}=82.5-191.0 \mathrm{~mm}, \mathrm{r}=$ 11.2-22.1 mm), bottom sledge, 1399-1422 m (EMU8999A, B).

TALUD X, St. $14\left(27^{\circ} 44^{\prime} 48^{\prime \prime}\right.$ N, $\left.111^{\circ} 36^{\prime} 54^{\prime \prime} \mathrm{W}\right), 11 /$ February/2007, 75 specimens $(\mathrm{R}=19.7-57.7 \mathrm{~mm}, \mathrm{r}=2.9$ $7.1 \mathrm{~mm})($ EMU-9000A, B), three specimens $(\mathrm{R}=34.9-39.7$ $\mathrm{mm}, \mathrm{r}=4.2-5.1 \mathrm{~mm}$ ) (ICML-UNAM 2.203.0), and three specimens $(\mathrm{R}=28.9-41.6 \mathrm{~mm}, \mathrm{r}=5.2-6.2 \mathrm{~mm})(\mathrm{USNM}-$ 
1146560), bottom sledge, $905-943 \mathrm{~m}$.

TALUD X, St. 25 (26 $\left.39^{\circ} 04^{\prime \prime N}, 111^{\circ} 18^{\prime} 20^{\prime \prime} \mathrm{W}\right), 14 /$ February/2007, six specimens $(\mathrm{R}=16.3-47.5 \mathrm{~mm}, \mathrm{r}=2.8$ $6.0 \mathrm{~mm}$ ), bottom sledge, 837-840 m (EMU-9001) (Fig. 5). Previous records in Mexico. "Albatross" St. 5688 $\left(27^{\circ} 38^{\prime} 5^{\prime} \mathrm{N} 115^{\circ} 17^{\prime} 40^{\prime \prime} \mathrm{W}\right)$, of Cedros Island, Baja California, 960 m (525 fms.) (H. L. Clark, 1913); St. 2992 , off Clarion Island, 842 m (460 fms.) (A. H. Clark, 1916; as Saraster insignis); St. 4381 (32²6’00”N 117¹8'0”'W) (ca Coronados I.) (Fisher, 1911b) (Fig. 5).

Distribution and ecology. Type locality between San Diego and San Clemente Island, California, USA, $992 \mathrm{~m}$ (542 fms.). Alaska Peninsula, USA to off Clarion Island, Mexico, in 466-1 $903 \mathrm{~m}$ (Maluf, 1988). The material collected during this study (in depths of 837-1 $422 \mathrm{~m}$ ) was obtained within the known depth range of this species. This increases the distribution range of this species to the southern and central Gulf of California. Epibenthic temperature and dissolved oxygen concentration: $4.38^{\circ} \mathrm{C}$ $\left(39.9^{\circ} \mathrm{F}\right)$ (H. L. Clark, 1913); 3.19-5.75 $\mathrm{C}$ and 0.03-0.44 ml $\mathrm{O}_{2} / 1$ (this study).

\section{Remarks}

Nearchaster forms a wide-ranging species complex that includes the more southern ranging $N$. aciculosus with $N$. variabilis and $N$. pedicellaris ranging north to the Sea of Okhotsk.

Pectinaster agassizii (Ludwig, 1905)

Fig. 4C, D

Cheiraster agassizii Ludwig, 1905: 1, pl. I, figs. 3, 4, pl. II, figs. 5-12, pl. XVI, figs. 81-84.

Cheiraster agassizii evoplus Fisher, 1910b: 551 (off San Diego, California).

Pectinaster agassizii.- Ludwig, 1910 : 449.- H. L. Clark, 1913: 191; 1920: 82; 1923: 149.- Maluf, 1988: 33 (table), 117 (list); 1991: 348 (list).- Maluf and Brusca, 2005: 330 (list).

Pectinaster agassizi.- Luke, 1982: 13.

Pectinaster agassizi evoplus.- Fisher, 1911b: 123, pl. 28, figs. 1, 2, pl. 55, figs. 4, 4a, pl. 57, fig. 1; 1930: 191 (list).Alton, 1966: 1697.- Luke, 1982: 13.

Cheiraster agassizii.- Solís-Marín et al., 2005: 125.
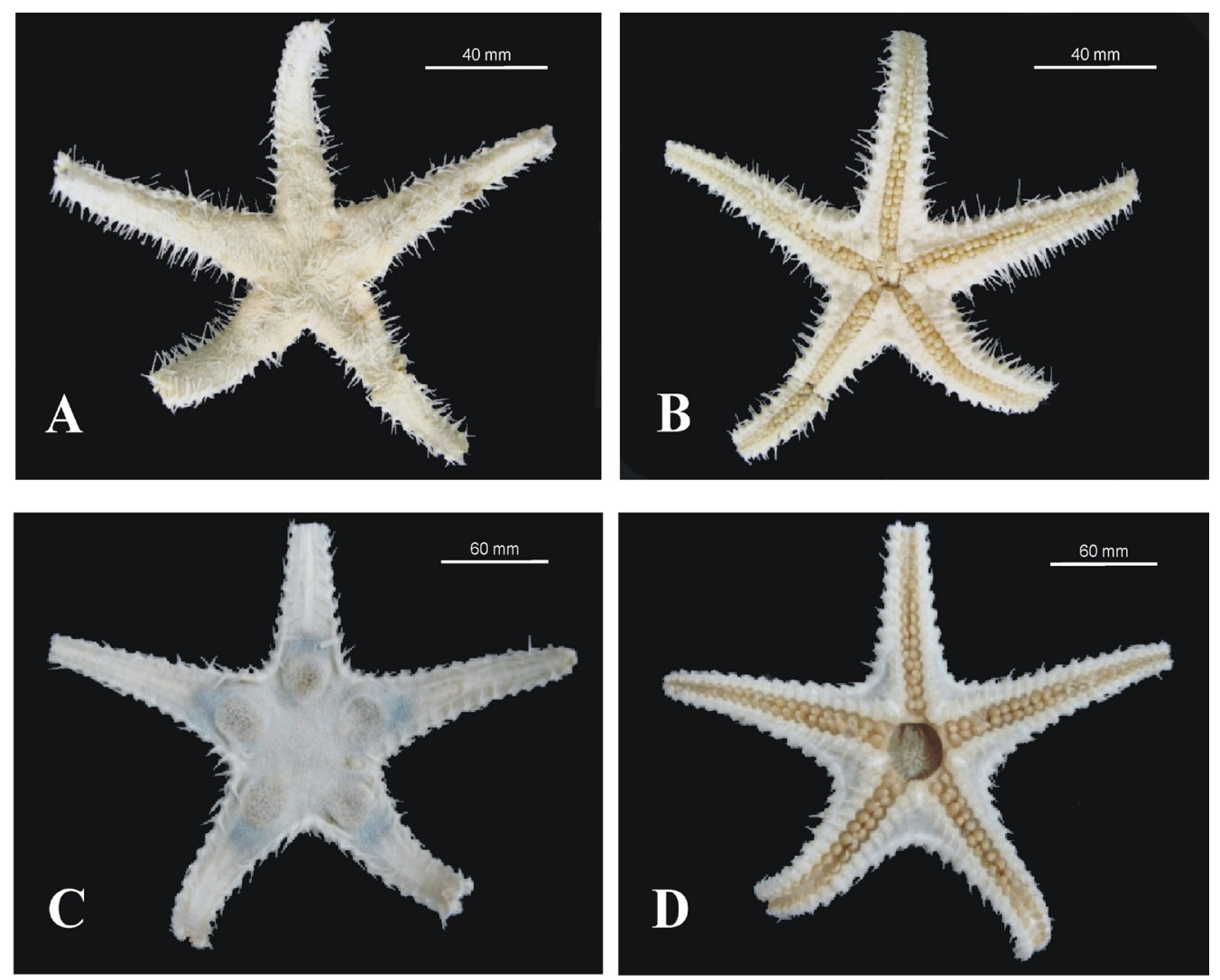

Figure 4. Notomyotida. A. Nearchaster aciculosus (Fisher, 1910), aboral view. B. Same, oral view. C. Pectinaster agassizii (Ludwig, 1905), aboral view. D. Same, oral view. 


\section{Taxonomic summary}

Material examined. TALUD IV, St. $19\left(24^{\circ} 15^{\prime} 18^{\prime \prime} \mathrm{N}\right.$, $\left.108^{\circ} 24^{\prime} 06^{\prime} \mathrm{W}\right), \quad 25 /$ August $/ 2000$, one specimen $(\mathrm{R}=60.9 \mathrm{~mm}, \mathrm{r}=12.0 \mathrm{~mm}$ ), bottom sledge, $1240-1245 \mathrm{~m}$ (EMU-9002).

TALUD IV, St. 34 (2540'41”N, 109 54'24”W), $27 /$ August $/ 2000$, one specimen $(\mathrm{R}=84.6 \mathrm{~mm}, \mathrm{r}=13.7 \mathrm{~mm})$, bottom sledge, 1240-1250 m (EMU-9003).

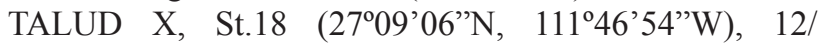
February/2007, two specimens $(\mathrm{R}=94.5-155.5 \mathrm{~mm}$, $\mathrm{r}=16.3-16.5 \mathrm{~mm})$, bottom sledge, $1526 \mathrm{~m}$ (EMU-9004A, B) (Fig. 5).

Previous records in Mexico. "Albatross" Sts. 3431 $\left(23^{\circ} 59^{\prime} \mathrm{N}, 108^{\circ} 40^{\prime} \mathrm{W}\right)$ and $3435\left(26^{\circ} 48^{\prime} \mathrm{N}, 110^{\circ} 45^{\prime} \mathrm{W}\right)$, Gulf of California, 1271-2323 m depth (Ludwig, 1905). Off Punta Santo Tomas (“Albatross" Sts.: 5673, 31 ${ }^{\circ} 26^{\prime}$ N, $117^{\circ} 42^{\prime} \mathrm{W} ; 5674,31^{\circ} 28^{\prime} 45^{\prime \prime} \mathrm{N}, 17^{\circ} 09^{\prime} 50^{\prime \prime} \mathrm{W}$; and 5692 , $31^{\circ} 23^{\prime} 45^{\prime}$ 'N , $118^{\circ} 31^{\prime} 30^{\prime \prime} \mathrm{W}$ ); off Ballenas Bay (Sts. 5686, $26^{\circ} 14^{\prime} \mathrm{N}, 114^{\circ} \mathrm{W}$; and $5689,29^{\circ} 23^{\prime} \mathrm{N}, 116^{\circ} 14^{\prime} \mathrm{W}$ ); and

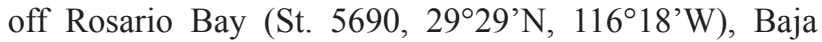
California, in depths of 1080-1995 m (590-1090 fms.) (H. L. Clark, 1913).
Off Descanso Bay $\left(32^{\circ} 05^{\prime} 12^{\prime}\right.$ N, $\left.117^{\circ} 14^{\prime} \mathrm{W}\right)$, N. of Cedros Island (28 55'18'N, 115 45'54'W), and off San Hipolito Bay (26 26' $\left.12^{\prime \prime} \mathrm{N}, 114^{\circ} 07^{\prime} 06^{\prime \prime} \mathrm{W}\right)$, Baja California, in depths of 1244-2136 m; SW of Cabo San Lucas $\left(22^{\circ} 42^{\prime} 30^{\prime \prime} \mathrm{N}\right.$, $110^{\circ} 21^{\prime} \mathrm{W}$; $\left.22^{\circ} 45^{\circ} \mathrm{N}, 110^{\circ} 23^{\prime} \mathrm{W}\right)$, Baja California Sur, in depths of 1893-2014 m (as P. agassizi evoplus) (Luke, 1982). Gulf of California ( $\left.25^{\circ} 18^{\prime} \mathrm{N}, 110^{\circ} 19^{\prime} 30^{\prime \prime} \mathrm{W}\right)$, in depths of 1244-1908 m (Luke, 1982). The record off Baja California Sur, Gulf of California by Solís-Marín et al. (2005) corresponds to material collected by the "Albatross" (Solís-Marín, pers. comm.) (Fig. 5).

Distribution and ecology. Syntypes from Panama, off the Cocos and Galapagos Islands, and in the Gulf of California. Southern California Borderland to Panama (Punta Mariato), and off the Galapagos, Coco, and Malpelo Islands; Indian Ocean. At depths: 790-2 323 m (Maluf, 1988; Maluf and Brusca, 2005). Off northern Oregon (Alton, 1966). The material collected during this study (in depths of $1240-1526 \mathrm{~m}$ ) was obtained within the known depth range of this species. Other species of Pectinaster are recorded as feeding primarily on sediment, mollusks and crustaceans (Carey, 1972). Epibenthic temperature and dissolved oxygen concentration: $2.39-3.8^{\circ} \mathrm{C}$ (Ludwig,

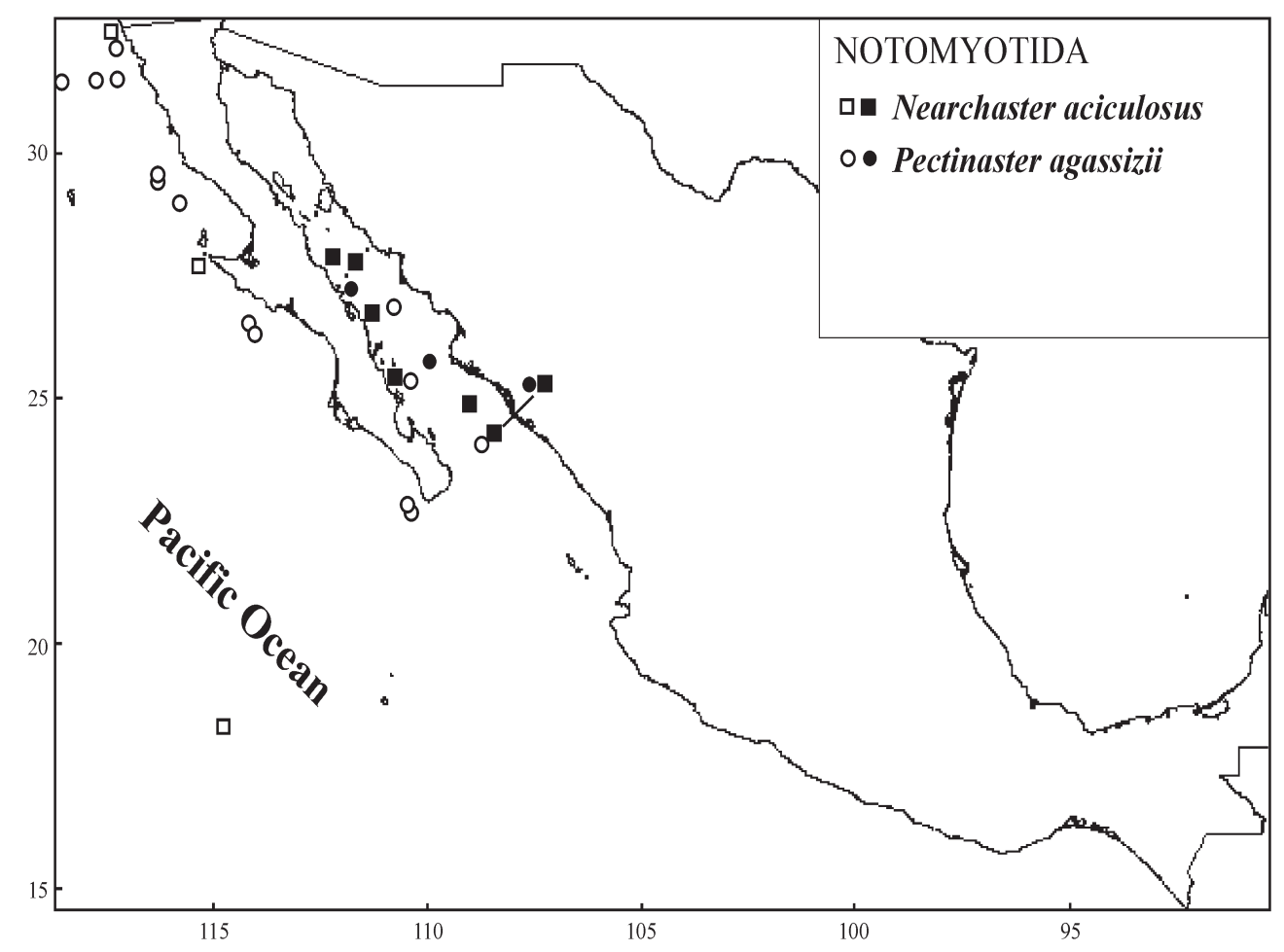

Figure 5. Distribution of examined species of Notomyotida off the Pacific coast of Mexico, including previous records (open symbols) and localities where material was collected during the TALUD survey (solid symbols). 
1905); $2.83-4.11^{\circ} \mathrm{C}\left(37.1-39.4^{\circ} \mathrm{F}\right)$ (H. L. Clark, 1913); 3.17$3.69{ }^{\circ} \mathrm{C}$ and $0.59-0.79 \mathrm{ml} \mathrm{O}_{2} / 1$ (this study).

\section{Remarks}

Similar to Nearchaster, species in Pectinaster are wide-ranging but generally very similar in morphology, suggesting that they are all part of a broadly distributed species complex (Fisher, 1911b). Morphological boundaries between species across a range can often be difficult to distinguish.

Order Valvatida

Family Goniasteridae

Ceramaster leptoceramus (Fisher, 1905)

Fig. 6A, B

Tosia leptocerama Fisher, 1905: 306

Ceramaster leptoceramus.- Fisher, 1911b: 206 (key), 210, pl. 39, figs. 1-3, pl. 58, figs. 3, 3a, pl. 60, fig. 2; 1930: 192 (list).- H. L. Clark, 1913: 193; 1923: 150.- Blake, 1973: 51.- Muscat, 1980: 264.- Luke, 1982: 14.- Maluf, 1988: 33 (table), 118 (list).

\section{Taxonomic summary}

Material examined. TALUD IV, St. 25 (2451'42”N, $\left.108^{\circ} 57^{\prime} 54^{\prime \prime} \mathrm{W}\right), 26 /$ August/2000, one specimen $(\mathrm{R}=13.6$ $\mathrm{mm}, \mathrm{r}=7.5 \mathrm{~mm}$ ), bottom sledge, $789 \mathrm{~m}$ (EMU-8986).

TALUD V, St. $18\left(24^{\circ} 15^{\prime} 12^{\prime \prime} \mathrm{N}, 108^{\circ} 17^{\prime} 06^{\prime} \mathrm{W}\right), 15 /$ December/2000, one specimen $(\mathrm{R}=40.6 \mathrm{~mm}, \mathrm{r}=26.1$ $\mathrm{mm}$ ), bottom sledge, 940-990 m (EMU-8987).

TALUD VIII, St. 16 (25'24’24”N, 110³7'36”W), 18/ April/2005, one specimen $(\mathrm{R}=18.5 \mathrm{~mm}, \mathrm{r}=13.3 \mathrm{~mm})$, bottom sledge, $1030 \mathrm{~m}$ (EMU-8988).

TALUD X, St. $4\left(28^{\circ} 16^{\prime} 06^{\prime}\right.$ N, $\left.112^{\circ} 32^{\prime} 48^{\prime \prime}\right), 9 /$ February/2007, five specimens, $(\mathrm{R}=8.0-30.4 \mathrm{~mm}, \mathrm{r}=$ 5.4-16.9 mm) (EMU-8990A, B), two specimens $(\mathrm{R}=11.5$ $12.1 \mathrm{~mm}, \mathrm{r}=8.0 \mathrm{~mm}$ ) (ICML-UNAM 2.183.1), and three specimens $(\mathrm{R}=15.3-22.3 \mathrm{~mm}, \mathrm{r}=9.1-13.0 \mathrm{~mm})$ (USNM1146563), bottom sledge, 587-633 m (Fig. 7).

Previous records in Mexico. "Albatross" St. 5675

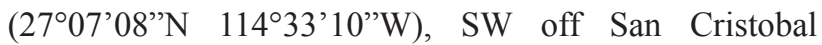
Bay, Baja California, 520 m (284 fms.). Off Salina Cruz (14 $\left.{ }^{\circ} 50^{\prime} \mathrm{N}, 96^{\circ} 15^{\prime} \mathrm{W}\right)$, Gulf of Tehuantepec, 1042-1134 m depth (Luke 1982) (Fig. 7).

Distribution and ecology. Type locality, "Albatross" St. $4378\left(32^{\circ} 42^{\prime} 0^{\prime \prime} \mathrm{N} 117^{\circ} 14^{\prime} 0^{\prime \prime} \mathrm{W}\right)$, off Point Loma, San Diego, California, USA, 688-1 087 m (376-594 fms.). From Conception Point, California, USA, to off Chicama, Chile, in depths of 366-1 811 m (Maluf, 1988). Present records extend the distribution of this species to the SE, SW and central Gulf of California, in depths of 587-1 $030 \mathrm{~m}$. Epibenthic temperature and dissolved oxygen concentration: $7^{\circ} \mathrm{C}\left(44.6^{\circ} \mathrm{F}\right)(\mathrm{H}$. L. Clark, 1923); $5.00-8.22^{\circ} \mathrm{C}$ and $0.15-0.38 \mathrm{ml} \mathrm{O}_{2} / 1$ (this study).

\section{Remarks}

This species appears to be 1 of several Ceramaster spp. occurring in the North Pacific, including C. japonicus (Sladen, 1889), C. patagonicus (Sladen, 1889), C. clarki Fisher, 1910, and C. arcticus (Verrill, 1909) which may form a species complex along the continental shelf of North America. However, Fisher (1911) noted that $C$. leptoceramus showed no intergradation with C. japonicus. Further sampling to show the range of Ceramaster along the coast is needed.

Mediaster transfuga Ludwig, 1905

Fig. 6C, D

Mediaster transfuga Ludwig, 1905: 120, pl. VIII, figs. 44, 45, pl. XXII, figs. 122-125, pl. XXV, figs. 139-141.

Mediaster tenellus.- Maluf, 1988: 34 (table), 118 (list) (part, the record of M. transfuga).

\section{Taxonomic summary}

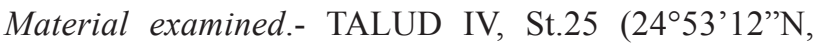
$\left.108^{\circ} 59^{\prime} 24^{\prime \prime} \mathrm{W}\right), 26 /$ August $/ 2000$, one specimen $(\mathrm{R}=$ $43.5 \mathrm{~mm}, \mathrm{r}=11.1 \mathrm{~mm}$ ), bottom sledge, $778-800 \mathrm{~m}$ (EMU-8993).

TALUDV, St. $11\left(23^{\circ} 15^{\prime} \mathrm{N}, 106^{\circ} 59^{\prime} \mathrm{W}\right), 18 /$ December/2000, two specimens $(\mathrm{R}=47.4-54.2 \mathrm{~mm}, \mathrm{r}=12.6-17.0 \mathrm{~mm})$, bottom sledge, $860 \mathrm{~m}$ (EMU-8994) (Fig. 7).

Previous records in Mexico. Type locality, "Albatross" St. 3417 (16 $\left.32^{\circ} \mathrm{N}, 99^{\circ} 48^{\prime} \mathrm{W}\right)$, off Guerrero, $902 \mathrm{~m}$ depth (Fig. 7).

Distribution and ecology. M. transfuga is known from the type locality, at $902 \mathrm{~m}$ depth. The material collected during this study was obtained in depths of 778-860 $\mathrm{m}$ and extends its distribution range to the SE Gulf of California. Epibenthic temperature and dissolved oxygen concentration: $4.8^{\circ} \mathrm{C}$ (Ludwig, 1905 ); $5.03-5.40^{\circ} \mathrm{C}$ and $0.07-0.29 \mathrm{ml} \mathrm{O}_{2} / 1$ (this study).

\section{Remarks}

Material described herein conforms to the description of M. transfuga as described by Ludwig (1905). M. transfuga was thought by Fisher (1911b) to intergrade with the closely related Mediaster tenellus, possibly forming different morphological extremes of the same species. Maluf (1988) considered M. transfuga a synonym of M. tenellus whereas A. M. Clark's checklist (1913) 
retained the 2 species as separate. $M$. transfuga specimens examined herein showed a more weakly calcified body wall and slight differences from M. tenellus but several, including those listed by Fisher (1911b), are clearly shared. M. transfuga may represent a deeper-water form of M. tenellus, although a full revision of Mediaster spp., especially for those taxa in this region, is needed to fully address the question.

Nymphaster diomedeae Ludwig, 1905

Fig. 6E, F

Nymphaster diomedeae Ludwig, 1905: 128, pl. X, figs. 48, 49, 52, 53, pl. XI, figs. 54, 55.

Nymphaster diomedeae.- Fisher, 1928b: 490.- Maluf, 1988: 34 (table), 118 (list); 1991: 349 (list).- Maluf and Brusca, 2005: 331 (list).

\section{Taxonomic summary}

Material examined. TALUD VII, St. 13b (2330'18'N, $\left.107^{\circ} 44^{\prime} \mathrm{W}\right), 6 / \mathrm{June} / 2001,2$ specimens $(\mathrm{R}=19.9-47.5 \mathrm{~mm}$, $\mathrm{r}=6.2-19.3 \mathrm{~mm}$ ), bottom sledge, 1400-1450 m (EMU8995A, B) (Fig. 7).

Additional material. TALUD VI, St. $19\left(24^{\circ} 16^{\prime} 18^{\prime \prime N}\right.$, $\left.108^{\circ} 24^{\prime} 18^{\prime \prime} \mathrm{W}\right), 15 / \mathrm{March} / 2001$, one specimen $(\mathrm{R}=$ $13.2 \mathrm{~mm}, \mathrm{r}=3.3 \mathrm{~mm}$ ), bottom sledge, $1160-1200 \mathrm{~m}$. Uncatalogued.

Previous records in Mexico. Off Punta Piaxtla, SE Gulf of California, Mexico (Maluf, 1988). This is the only record provided by Maluf (1988) for the Gulf of California, and it certainly corresponds to material of the Allan Hancock Foundation presently deposited in the Natural History Museum of Los Angeles County. Data from this collection are: off Río Elata (="Río Elota", close to Punta Piaxtla), Sinaloa, Mexico, between $23^{\circ} 40^{\prime} 30^{\prime \prime} \mathrm{N}, 107^{\circ} 38^{\prime} 30^{\prime \prime} \mathrm{W}$, and $23^{\circ} 37^{\prime} 00^{\prime \prime} \mathrm{N}, 107^{\circ} 51^{\prime} 48^{\prime \prime} \mathrm{W}, 1367-1385 \mathrm{~m}$ (747-757 fms.) (Gordon Hendler, pers. comm.) (Fig. 7).

Distribution and ecology. Syntypes from Panama, and off the Cocos and the Galapagos Islands. Known only from the southern Gulf of California to the Gulf of Panama and the Galapagos Ridge, found in depths of 702-1 618 m (Ludwig, 1905; Maluf, 1988; Maluf and Brusca, 2005). The material collected during this study (in depths of 1 160-1 $450 \mathrm{~m}$ ) was obtained within the known depth range of this species and confirms the previous record along the SE coast of the Gulf of California. Epibenthic temperature and dissolved oxygen concentration: $2.89-6.28^{\circ} \mathrm{C}$ (Ludwig, 1905); 3.00$3.70^{\circ} \mathrm{C}$ and $0.73-1.04 \mathrm{ml} \mathrm{O}_{2} / 1$ (this study).

\section{Remarks}

This is one of the few records available for this species.
Fisher (1928b) cited 1 specimen from south of Cocos Island, in $1144 \mathrm{~m}$ (625 fms.) depth. This species may be closely related to the North Atlantic Nymphaster arenatus (Perrier, 1881), as separated from the East Pacific by the Panamian Isthmus.

Order Spinulosida

Family Echinasteridae

Henricia sp. 1

\section{Taxonomic summary}

Material examined. TALUD VIII, St. $11\left(24^{\circ} 54.5^{\prime} \mathrm{N}, 110^{\circ}\right.$ $\left.25.5^{\prime} \mathrm{W}\right), 17 /$ April $/ 2005$, one specimen $(\mathrm{R}=6.2 \mathrm{~mm} ; \mathrm{r}=1.9$ $\mathrm{mm}$ ), bottom sledge, $920 \mathrm{~m}$ (EMU-9009).

TALUD X, St. 4 (28 $\left.16^{\circ} 06^{\prime}{ }^{\prime} \mathrm{N}, 112^{\circ} 32^{\prime} 48^{\prime \prime} \mathrm{W}\right), 9 /$ February/2007, seven specimens $(\mathrm{R}=9.9-31.8 \mathrm{~mm} ; \mathrm{r}=2.0$ $6.7 \mathrm{~mm}$ ), bottom sledge, 587-633 m (EMU-9010A) (Fig. 8).

\section{Remarks}

According to Maluf $(1988: 42,43)$ there are 8 species of Henricia known to the central eastern Pacific, all except $H$. nana (Ludwig, 1905) with at least 1 record in Mexican waters. Henricia represents a highly diverse, but morphologically difficult group with a widespread distribution. In addition to upcoming molecular revision for this group (Eernisse et al., pers. comm.), there are problematic boundaries for several of the species listed as occurring in this region by Maluf (1988). The shallowwater H. leviuscula (Stimpson, 1857), for example, represent up to 4 different cryptic species (Eernisse and Strathmann, pers. comm., 2005). Thus full descriptions of these 2 species should accompany the monograph for Henricia in this region.

\section{Henricia sp. 2}

\section{Taxonomic summary}

Material examined. TALUD X, St. $4\left(28^{\circ} 16^{\prime} 06^{\prime \prime} \mathrm{N}\right.$, $\left.112^{\circ} 32^{\prime} 48^{\prime \prime} \mathrm{W}\right)$, four specimens $(\mathrm{R}=41.3-43.6 \mathrm{~mm}$; $\mathrm{r}=$ 6.7-7.4 mm), 9/February/2007, benthic sledge, $587-633 \mathrm{~m}$ (EMU-9011A) (Fig. 8).

\section{Remarks}

See above.

Order Velatida

Family Solasteridae 

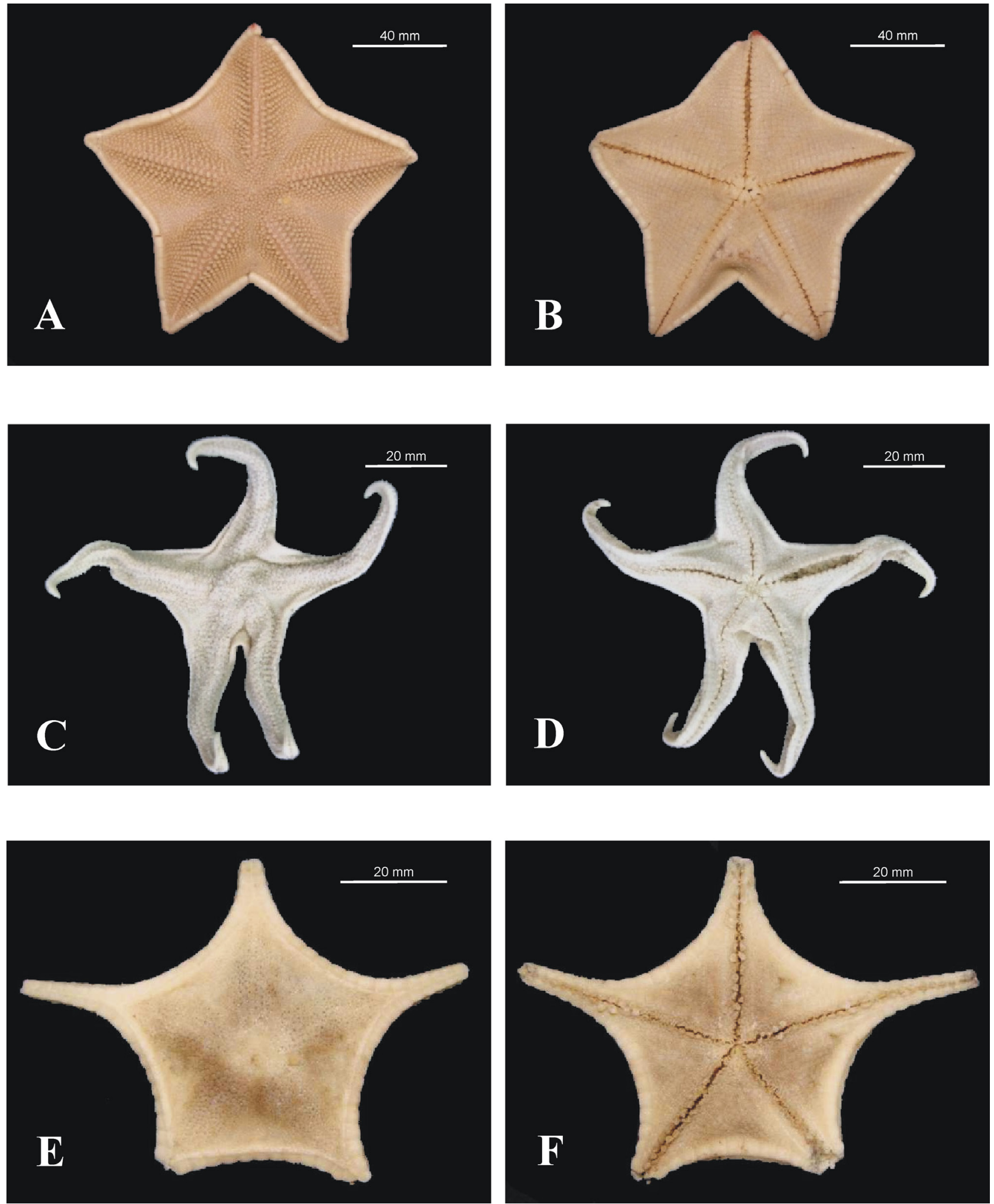

Figure 6. Valvatida. A. Ceramaster leptoceramus (Fisher, 1905), aboral view. B, same, oral view. C. Mediaster transfuga Ludwig, 1905, aboral view. D. Same, oral view. E. Nymphaster diomedeae Ludwig, 1905, aboral view. F, same, oral view. 


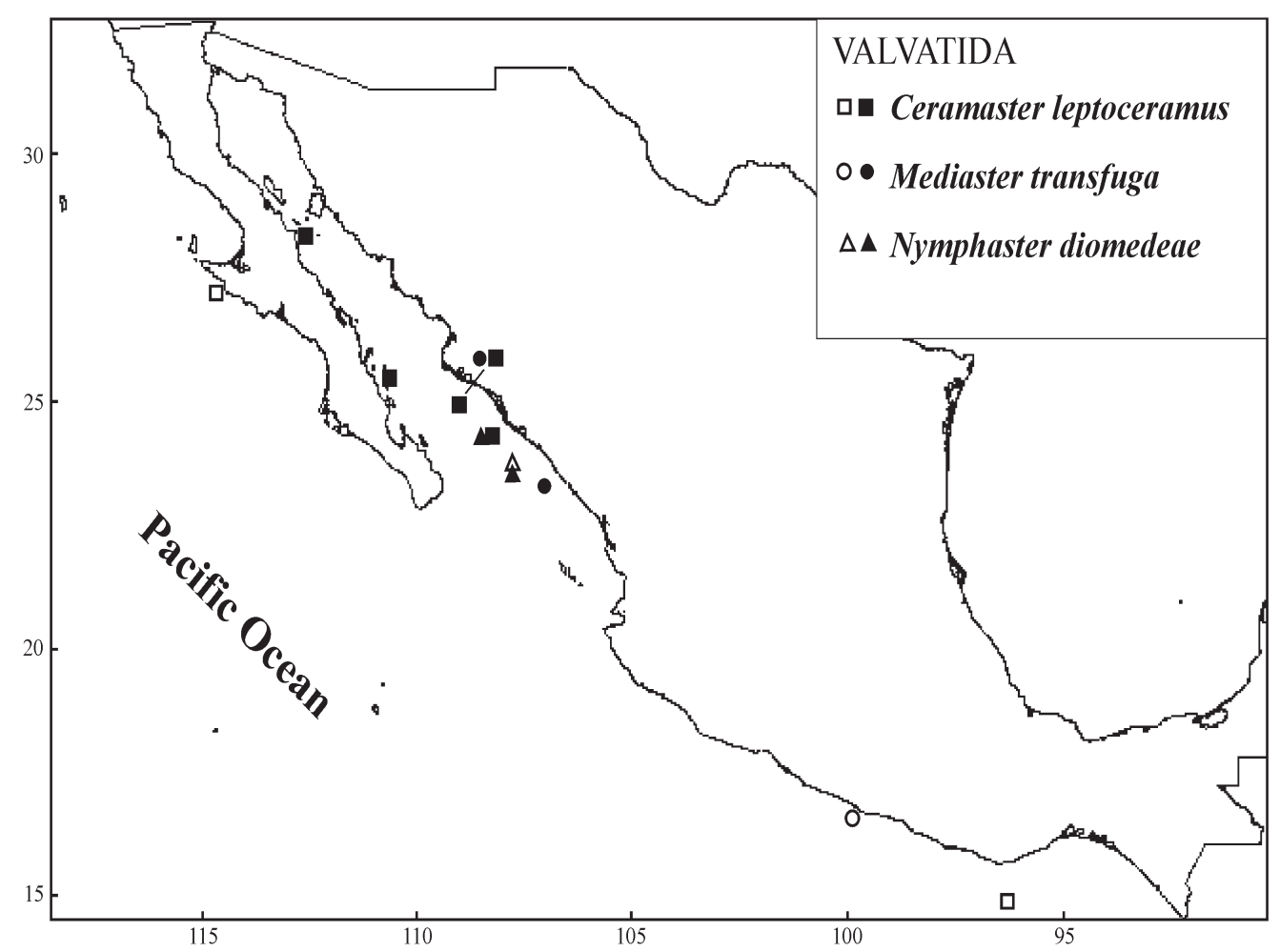

Figure 7. Distribution of examined species of Valvatida off the Pacific coast of Mexico, including previous records (open symbols) and localities where material was collected during the TALUD survey (solid symbols).

Lophaster furcilliger Fisher, 1905

Fig. 9A, B

Lophaster furcilliger Fisher, 1905: 312.

Lophaster furcilliger vexator Fisher, 1910c: 574 (off Punta Arena, Northern California); 1930: 198 (list).

Lophaster furcilliger.- Fisher, 1911b: 334, pl. 79, figs. 1, 2, pl. 114, figs. 1, 1a-g, pl. 116, fig. 5; 1930: 198 (list).- H. L. Clark, 1913: 197; 1923: 151.- Alton, 1966: 1706.- Muscat, 1980: 265.- Maluf, 1988: 39 (table), 122 (list); 1991: 350 (list).

\section{Taxonomic summary}

Material examined. TALUD VIII, St. $11\left(24^{\circ} 54^{\prime} 24^{\prime \prime} \mathrm{N}\right.$, $\left.110^{\circ} 25^{\prime} 30^{\prime \prime} \mathrm{W}\right), 12$ specimens $(\mathrm{R}=6.2-27.1 \mathrm{~mm}, \mathrm{r}=1.9$ $10.7 \mathrm{~mm})($ EMU-9005A, B), two specimens $(\mathrm{R}=16.6-19.9$ $\mathrm{mm}, \mathrm{r}=5.0-6.0 \mathrm{~mm}$ ) (ICML-UNAM 2.199.1), and three specimens $(\mathrm{R}=14.2-27.5 \mathrm{~mm}, \mathrm{r}=4.7-6.6 \mathrm{~mm})(\mathrm{USNM}-$ 1146559), 17/April/2005, bottom sledge $920 \mathrm{~m}$.

TALUD X, St. 4 (28 $\left.16^{\prime} 06^{\prime} \mathrm{N}, 112^{\circ} 32^{\prime} 48^{\prime \prime} \mathrm{W}\right), 9 /$ February/2007, one specimen $(\mathrm{R}=31.0 \mathrm{~mm}, \mathrm{r}=7.4 \mathrm{~mm})$, bottom sledge, 587-633 m (EMU-9006).

TALUD X, St. 5 (28 $\left.14^{\prime} 50^{\prime \prime N}, 112^{\circ} 24^{\prime} 53^{\prime \prime} \mathrm{W}\right), 19$ specimens $(\mathrm{R}=12.6-46.2 \mathrm{~mm}, \mathrm{r}=6.1-13.5 \mathrm{~mm}), 9 /$ February/2007, bottom sledge 820-837 m (EMU-9007A and USNM-1146566) (Fig. 8).

Previous records in Mexico. Off the west coast of Baja California (ca $28^{\circ} 20^{\prime} \mathrm{N}, 32^{\circ} \mathrm{N}$, and $32^{\circ} 20^{\prime} \mathrm{N}$ ) (Maluf, 1988) (Fig. 8).

Distribution and ecology. Type locality, "Albatross" St. $4425\left(33^{\circ} 14^{\prime} 0^{\prime \prime} \mathrm{N} 119^{\circ} 29^{\prime} 0^{\prime \prime} \mathrm{W}\right), 1$ 984-2 $013 \mathrm{~m}$ (1 084-1 100 fms.), between Santa Barbara and San Nicholas Island, California, USA; Alaska, USA, to the Galapagos Islands, in 86-2 $012 \mathrm{~m}$ (Maluf, 1988). To $2852 \mathrm{~m}$ (Alton, 1966). The material collected during this study (in depths of 587-920 m) was obtained within the known depth range of this species. This increases the distribution range of this species to the SW and central Gulf of California. Epibenthic temperature and dissolved oxygen concentration: $3.3-3.8^{\circ} \mathrm{C}\left(37.9-38.9^{\circ} \mathrm{F}\right)(\mathrm{H}$. L. Clark, 1913); $5.00-8.22{ }^{\circ} \mathrm{C}$ and $0.11-0.38 \mathrm{ml} \mathrm{O}_{2} / 1$ (this study).

Korethrasteridae Danielssen \& Koren, 1884

Peribolaster biserialis Fisher, 1905

Fig. 9C, D

Peribolaster biserialis Fisher, 1905: 313; 1911b: 341, pl. 97, figs. 1, 2, pl. 114, figs. 3, 3a-c, pl. 115, fig. 5.- H. L. Clark, 1913: 197.- Djakonov, 1950: 76.- Baranova, 1957: 16.- Maluf, 1988: 122 (text), p. 40, (table), 122 (list).Lambert, 2000: 28 (checklist).- A. M. Clark, 1996: 216. 


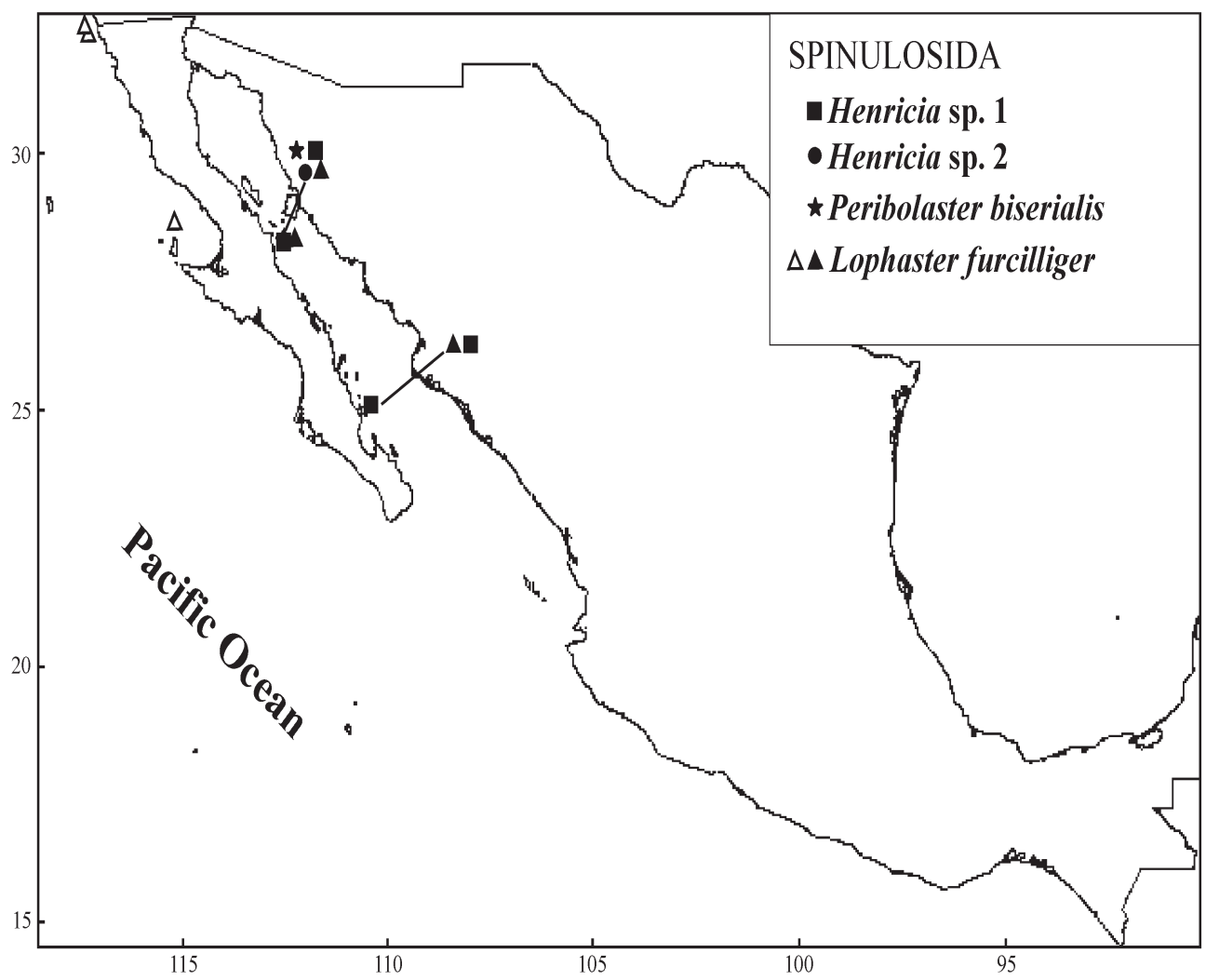

Figure 8. Distribution of examined species of Spinulosida off the Pacific coast of Mexico, including previous records (open symbols) and localities where material was collected during the TALUD survey (solid symbols).

\section{Taxonomic summary}

Material examined. TALUD X, St. $4\left(28^{\circ} 16^{\prime} 06^{\prime \prime} \mathrm{N}\right.$, $\left.112^{\circ} 32^{\prime} 48^{\prime \prime} \mathrm{W}\right)$, one specimen $(\mathrm{R}=31.5 \mathrm{~mm}, \mathrm{r}=8.1$ $\mathrm{mm})$, 9/February/2007, benthic sledge, 587-633 m (EMU-9008A).

Previous records in Mexico. None.

Distribution and ecology. Type locality, "Albatross" St. $4410\left(33^{\circ} 23^{\prime} \mathrm{N}, 118^{\circ} 25^{\prime} \mathrm{W}\right)$, California, USA, 325-357 m (178-195 fms.) (Fisher, 1905). Bering Sea to Southern California, in depths of 104-805 m (Maluf, 1988). This present record is the first for Mexico and the Gulf of California (Fig. 8). The unique specimen collected during the TALUD X cruise was found at a depth included in the depth range of the species. Epibenthic temperature and dissolved oxygen concentration: $4.4^{\circ} \mathrm{C}\left(39.9^{\circ} \mathrm{F}\right)(\mathrm{H}$. L. Clark, 1913); $8.22{ }^{\circ} \mathrm{C}$ and $0.38 \mathrm{ml} \mathrm{O}_{2} / 1$ (this study).

\section{Remarks}

Another species of this genus, $P$. folicullatus Sladen, 1889, is reported from off Chile (Fisher, 1911b).
Order Forcipulatida

Family Pedicellasteridae

Ampheraster chiroplus Fisher, 1928

Fig. 10A, B

Ampheraster chiroplus Fisher, 1928 a: 81 (key), 84, pl. 31, figs. 3, 3a-d, pl. 32, fig. 2, pl. 35, fig. 2, pl. 37, fig. 2; 1930: 201 (list).- Alton, 1966: 1710.- Muscat, 1980: 265.- Maluf, 1988: 45 (table), 126 (list).

\section{Taxonomic summary}

Material examined. TALUD VIII, St. 11 (24'54'24'N, $\left.110^{\circ} 25^{\prime} 30^{\prime \prime} \mathrm{W}\right), 17 /$ April/2005, one specimen $(\mathrm{R}=50.3$ $\mathrm{mm}, \mathrm{r}=9.6 \mathrm{~mm}$ ), bottom sledge, $920 \mathrm{~m}$ (EMU-8981) (Fig. 11A).

Previous records in Mexico. None.

Distribution and ecology. Known from the type locality, "Albatross" St. 4427 (3402'0”N, 119³1'0”W), off Santa Cruz Island, California, in depths of 818-933 $\mathrm{m}$ (447-510 fms.) (Fisher, 1928a), and from northern Oregon, 732 m (400 fms.) (Alton, 1966). Maluf (1988: 

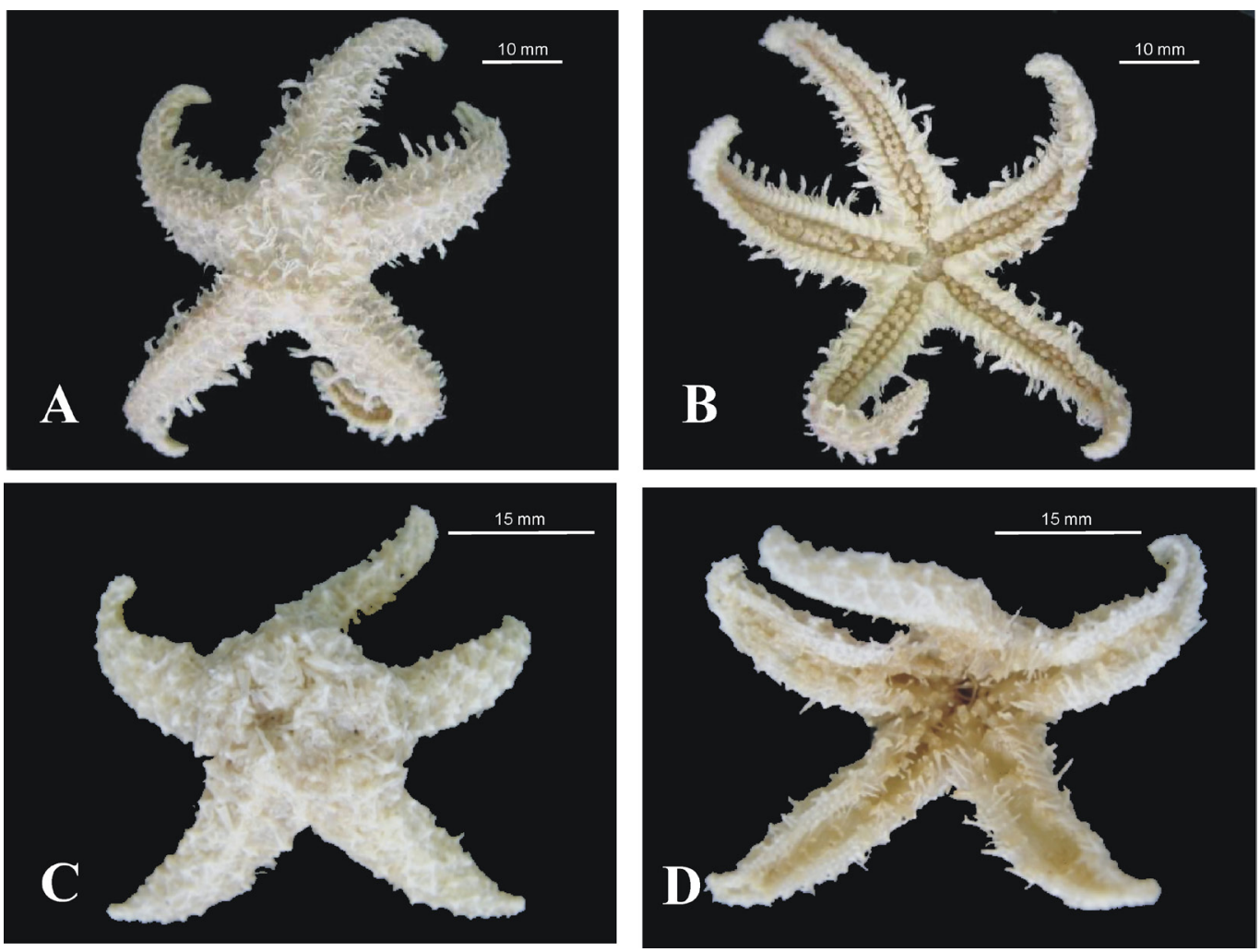

Figure 9. Spinulosida. A. Lophaster furcilliger Fisher, 1905, aboral view. B. Same, oral view. C. Peribolaster biserialis Fisher, 1905, aboral view. D. Same, oral view.

45) reports only the type locality for this species, but indicated a depth range of 417-933 m, probably due to a conversion error from fathoms to meters. The present record extends the distribution of this species to the SW Gulf of California, at a depth similar to the one registered at the type locality. Epibenthic temperature and dissolved oxygen concentration: $5.0^{\circ} \mathrm{C}$ and $0.20 \mathrm{ml}$ $\mathrm{O}_{2} / 1$ (this study).

\section{Remarks}

Ampheraster is a member of the uncommonly encountered Pedicellasteridae, which are characterized by the absence of an aboral carina, weakly calcified skeletons and biserial tubefoot rows (quadraserial tube feet proximally in some species). The 2 species included herein are distinguished by relatively few characteristics and may represent variations in 1 widely ranging species. Although some discrete differences in skeletal morphology support the separation between these more southern species from the northern A. marianus (Ludwig, 1905), several characters are shared, suggesting a close relationship.
Ampheraster hyperonchus (H. L. Clark, 1913)

Fig. 10C, D

Pedicellaster hyperonchus H. L. Clark, 1913: 201, pl. XLIV, figs. 3, 4.

Ampheraster hyperonchus.- Fisher, 1928 a: 81 (key).Maluf, 1988: 46 (table), 126 (list).

\section{Taxonomic summary}

Material examined. TALUD IV, St. 25 (24'51'47'N, $\left.108^{\circ} 57^{\prime} 59^{\prime \prime} \mathrm{W}\right), 26 /$ August $/ 2000$, two specimens ( $\mathrm{R}=$ 40.6-63.5 mm, $\mathrm{r}=3.8-5.8 \mathrm{~mm}$ ), bottom sledge, $778-800$ m (EMU-8982A, B).

TALUD IX, St. 17 (2520'54”N, 110 46'24”W), 13/ November/2005, one specimen $(\mathrm{R}=21.2 \mathrm{~mm}, \mathrm{r}=4.0$ $\mathrm{mm}$ ), bottom sledge, 826-846 m (EMU-8983).

TALUD X, St. $4\left(28^{\circ} 16^{\prime} 06^{\prime \prime} \mathrm{N}, 112^{\circ} 32^{\prime} 48^{\prime \prime} \mathrm{W}\right), 9 /$ February/2007, 14 specimens $(\mathrm{R}=15.7-30.5 \mathrm{~mm}, \mathrm{r}=2.7$ $5.2 \mathrm{~mm})($ EMU-8984A, B), two specimens $(\mathrm{R}=18.4-25.0$ $\mathrm{mm}, \mathrm{r}=2.9-3.8 \mathrm{~mm}$ ) (ICML-UNAM 2.202.0), and three specimens $(\mathrm{R}=20.6-23.5 \mathrm{~mm}, \mathrm{r}=2.8-3.8 \mathrm{~mm})$ (USNM1146562), bottom sledge, 587-633 m. 
TALUD X, St. 5 (28 $14^{\prime} 48^{\prime}$ N, 112 $\left.24^{\prime} 54^{\prime \prime} \mathrm{W}\right), 9 /$ February/2007, 2 specimens $(\mathrm{R}=11.7-16.7 \mathrm{~mm}, \mathrm{r}=1.9$ $2.41 \mathrm{~mm})$ (EMU-8992).

TALUD X, St. 14 (27 $\left.44^{\prime} 48^{\prime \prime} \mathrm{N}, 111^{\circ} 36^{\prime} 54^{\prime \prime} \mathrm{W}\right), 11 /$ February/2007, 7 specimens $(R=10-6-36.1 \mathrm{~mm}, \mathrm{r}=1.8$ $6.2 \mathrm{~mm})$ (EMU-8991 A, B).

Previous records in Mexico. Type locality, "Albatross" St. $5675\left(27^{\circ} 07^{\prime} 08^{\prime \prime} \mathrm{N}, 114^{\circ} 33^{\prime} 10^{\prime}\right.$ 'W), SW of San Cristobal Bay, west coast of Baja California, Mexico, 519 m (284 fms.) (H. L. Clark, 1913) (Fig. 11A).

Distribution and ecology. Only known from 2 localities in the East Pacific: the type locality in Mexico and northern Peru, in depths of $519 \mathrm{~m}$ (Maluf, 1988). Present records extend the distribution of this species to the SE, SW and central Gulf of California, in depths of 587$846 \mathrm{~m}$. Epibenthic temperature and dissolved oxygen concentration:); $7^{\circ} \mathrm{C}\left(44.6^{\circ} \mathrm{F}\right)$ (H. L. Clark, 1913); 5.03$8.22 \mathrm{C}$ and $0.03-0.38 \mathrm{ml} \mathrm{O}_{2} / 1$ (this study).

\section{Remarks}

See above.

Anteliaster coscinactis Fisher, 1923

Fig. 10E, F

Anteliaster coscinactis Fisher, 1923: 252.

Anteliaster coscinactis.- Fisher, 1928 a: 69 (key), 70, pl. 29, figs. 1, 1a-e, pl. 35, fig. 6, pl. 36, fig. 4, pl. 37, fig. 3; 1930: 201 (list).- Alton, 1966: 1711.- Maluf, 1988: 46 (table), 126 (list).

Anteliaster coscinactis megatretus Fisher, 1928 a: 69 (key), 71, pl. 29, figs. 2, 2a, 2b, pl. 35, figs. 5, 5a (off San Pablo Point, Baja California).

Pedicellaster improvisus.- H. L. Clark, 1913: 202 (by error).

Anteliaster coscinactes.- Muscat, 1980: 265.

\section{Taxonomic summary}

Material examined. TALUD VIII, St. 11 (245'ㄴ' $24^{\prime} \mathrm{N}$, $\left.110^{\circ} 25^{\prime} 30^{\prime \prime} \mathrm{W}\right), 17 / \mathrm{April} / 2005$, one specimen $(\mathrm{R}=33.5$ $\mathrm{mm}, \mathrm{r}=3.9 \mathrm{~mm}$ ), bottom sledge, $920 \mathrm{~m}$ (EMU-8985) (Fig. 11A).

Previous records in Mexico. Type locality of Anteliaster coscinactis megatretus, "Albatross" St. 5675, San Pablo

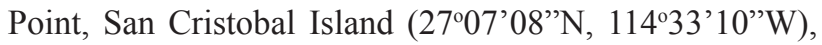
Baja California, 284 fms. (Fisher, 1923). Same station (“Albatross" St. 5675), as P. improvisus (H. L. Clark, 1913) (Fig. 11A).

Distribution and ecology. From Santa Cruz Island (type locality, “Albatross" St. 4427 (3402'0”N 119³1'0”W), 818-933 m (447-510 fms.), California, USA, to San
Cristobal Island, Baja California, Mexico, in depths of 519-933 m (Maluf, 1988). Also present off northern Oregon (Alton, 1966). This present record extends the distribution of this species to the SW Gulf of California, at a depth similar to its maximum known depth. Epibenthic temperature and dissolved oxygen concentration: $5.0^{\circ} \mathrm{C}$ and $0.20 \mathrm{ml} \mathrm{O}_{2} / 1$ (this study).

\section{Remarks}

Species of the genus Anteliaster are uncommonly encountered pedicellasterids, that are largely differentiated on the basis of papulae and pedicellariae, both of which are easily removed during turbulent collection methods, such as nets. The collection of more specimens showing better morphological details will further elucidate boundaries between species in Anteliaster. Anteliaster coscinactis megatretus was recognized as a junior synonym of the nominal subspecies, A. c. coscinactis, by Alton (1966: 1711).

Family Zoroasteridae

Myxoderma platyacanthum (H. L. Clark, 1913)

Fig. 12A, B

Zoroaster platyacanthus H. L. Clark, 1913: 199, pl. XLIV, figs. 1, 2; 1920: 95.

Myxoderma platyacanthum.- Fisher, 1919: 392 (key); 1928 a: 45 (key), 52, pl. 15, fig. 3, pl. 16, figs. 2, 2a, pl. 23, fig. 2, pl. 24, fig. 1, pl. 25, figs. 1, 2; 1930: 201 (list).H. L. Clark: 1920: 99 (key); 1923: 152.- Muscat, 1980: 266.- Maluf, 1988: 44 (table), 124 (list).- Solís-Marín et al. 2005: 126.- Mah, 2007: 192.

Myxoderma platyacanthum rhomaleum Fisher, 1919: 392 (key), 393 (text); 1928 a: 45 (key), 45 (text), 54, pl. 14, figs. 3, 3a, pl. 15, fig. 2, pl. 16, fig. 1, pl. 23, fig. 1, pl. 24, fig. 2, pl. 25, fig. 3; 1930: 201 (list).- Alton, 1966: 1709.

\section{Taxonomic summary}

Material examined. TALUD IV, St. $25\left(24^{\circ} 53^{\prime} 12^{\prime \prime} \mathrm{N}\right.$, $\left.108^{\circ} 59^{\prime} 24^{\prime \prime} \mathrm{W}\right), 26 /$ August $/ 2000$, one specimen $(\mathrm{R}=53.1$ $\mathrm{mm}, \mathrm{r}=7.4 \mathrm{~mm}$ ), bottom sledge, 835-870 m (EMU-8971). TALUD VI, St. $18\left(24^{\circ} 14^{\prime} 55^{\prime \prime} \mathrm{N}, 108^{\circ} 16^{\prime} 17^{\prime \prime} \mathrm{W}\right)$, three specimens $(\mathrm{R}=56.4-59.1 \mathrm{~mm}, \mathrm{r}=6.1-7.8 \mathrm{~mm}), 15 /$ March/2001, bottom sledge, 890-950 m(EMU-8972A, B).

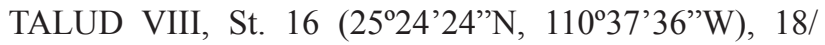
April $/ 2005$, one specimen $(\mathrm{R}=22.7 \mathrm{~mm}, \mathrm{r}=4.9 \mathrm{~mm})$, bottom sledge, $1030 \mathrm{~m}$ (EMU-8973).

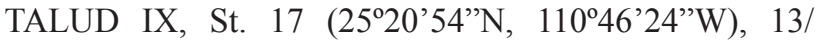
November/2005, two specimens $(R=20.0-21.0 \mathrm{~mm}$, $\mathrm{r}=4.3-4.5 \mathrm{~mm}$ ), bottom sledge, $836 \mathrm{~m}$ (EMU-8974).

TALUD X, St. 5 (28 $\left.14^{\prime} 48^{\prime \prime N}, 112^{\circ} 24^{\prime} 54^{\prime \prime} \mathrm{W}\right), 9 /$ 

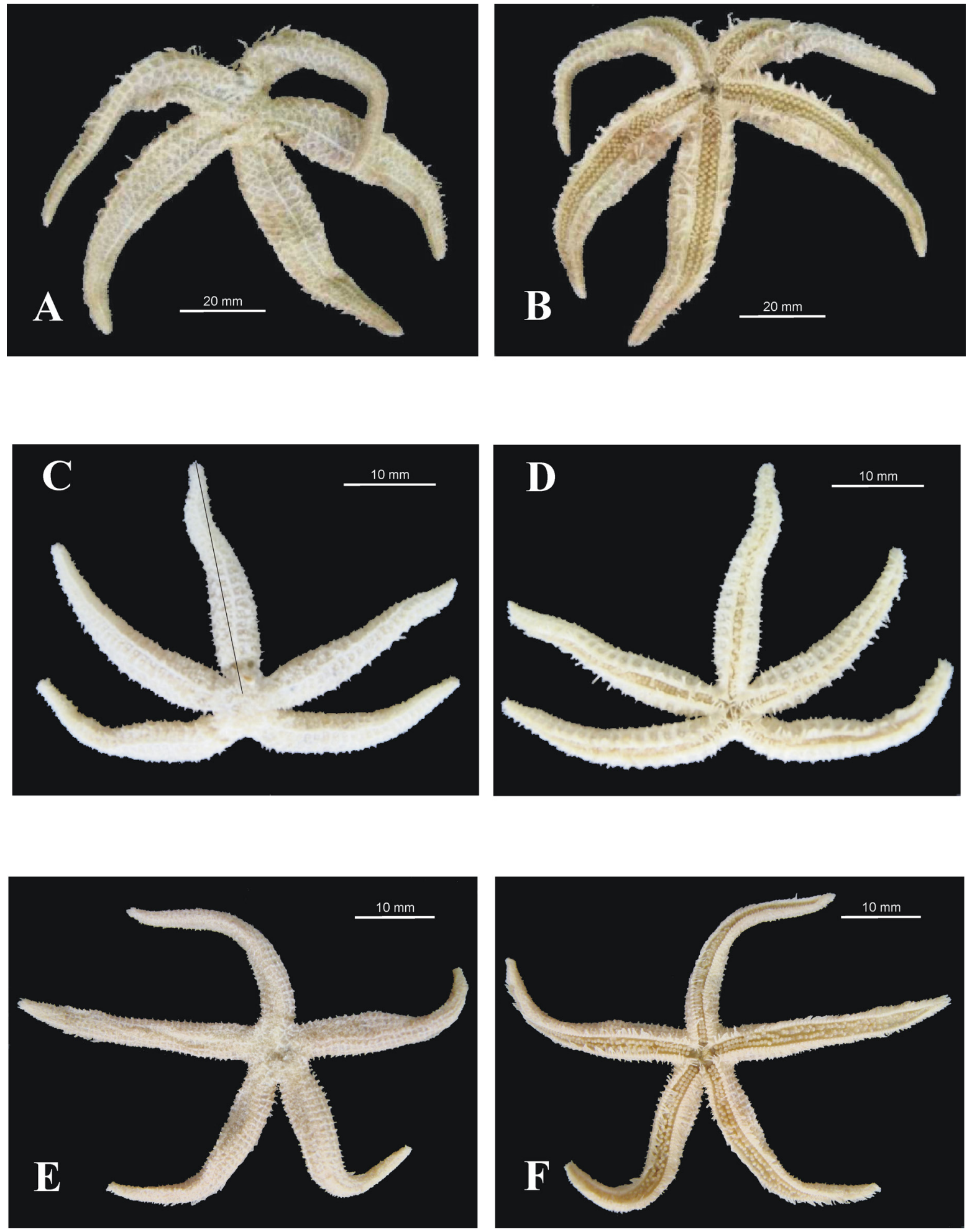

Figure 10. Forcipulatida. A. Ampheraster chiroplus Fisher, 1928, aboral view. B. Same, oral view. C. Ampheraster hyperonchus (H. L. Clark, 1913), aboral view. D. Same, oral view. E. Anteliaster coscinactis Fisher, 1923, aboral view. F. Same, oral view. 

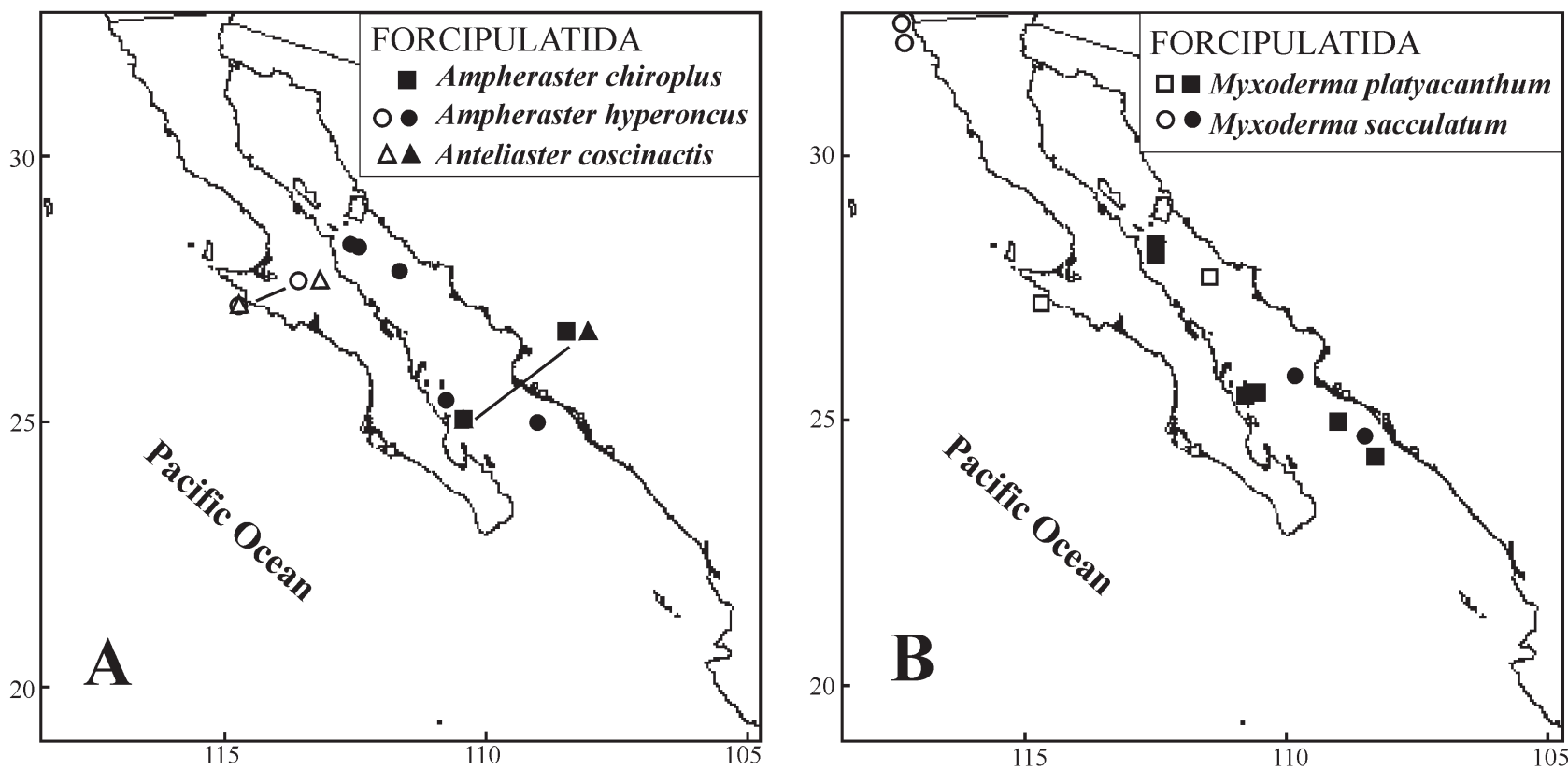

Figure 11. Distribution of examined species of Forcipulatida off the Pacific coast of Mexico, including previous records (open symbols) and localities where material was collected during the TALUD survey (solid symbols).

February/2007, four specimens $(\mathrm{R}=33.2-42.4 \mathrm{~mm}, \mathrm{r}=$ 8.5-11.3 mm) (EMU-8975), two specimens $(\mathrm{R}=28.2$ $32.7 \mathrm{~mm}, \mathrm{r}=5.2-5.7 \mathrm{~mm}$ ) (ICML-UNAM 2.129.4), and three specimens $(\mathrm{R}=20.0-35.0 \mathrm{~mm}, \mathrm{r}=3.3-5.4 \mathrm{~mm})$ (USNM-1146561), bottom sledge, 820-837 m.

TALUD X, St. 8 (28 $\left.05^{\prime} 54^{\prime \prime} \mathrm{N}, 112^{\circ} 26^{\prime} 48^{\prime \prime} \mathrm{W}\right), 10 /$ February/2007, one specimen $(\mathrm{R}=60.2 \mathrm{~mm}, \mathrm{r}=9.7 \mathrm{~mm})$, bottom sledge, 975-1007 m (EMU-8976).

Previous records in Mexico. Type locality, "Albatross"

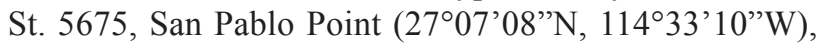
SW of San Cristobal Bay, 515 m (284 fms.) (H. L. Clark, 1923). Sonora (no precise locality; Solís-Marín, pers. comm.), Gulf of California (Solís-Marín et al., 2005). South of San Pedro Island $\left(27^{\circ} 40^{\prime} \mathrm{N}, 111^{\circ} 29^{\prime} 36^{\prime \prime} \mathrm{W}\right.$ to 27³2'06”N, 111'20’06”W), 931-952 m, Mexico (Mah, 2007) (Fig. 11B).

Distribution and ecology. Piedras Blancas Point, USA, to San Cristobal Bay, Baja California, Mexico, in depths of 256-768 m (Maluf, 1988). Off Sonora, central Gulf of California, Mexico (Solís-Marín et al., 2005). Present records confirm the presence of $M$. platyacanthum in the Gulf of California to off the State of Sonora, to ca $28^{\circ} 14^{\prime} \mathrm{N}$, Mexico, in depths of 820-1 $030 \mathrm{~m}$, slightly deeper that the deepest record known to date.

Gut contents from $M$. platyacanthum include ophiuroid ossicles and bivalves (Mah, 2007).

Epibenthic temperature and dissolved oxygen concentration: $7^{\circ} \mathrm{C}\left(44.6^{\circ} \mathrm{F}\right)(\mathrm{H}$. L. Clark, 1923); 4.25$6.65^{\circ} \mathrm{C}$ and $0.03-0.29 \mathrm{ml} \mathrm{O}_{2} / 1$ (this study). The type locality of Myxoderma platyacanthum rhomaleum is off

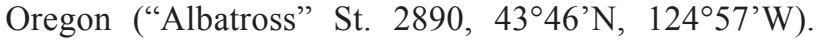
Fisher (1928 a) reports material from Oregon to Southern California, in depths of 507-542 m (277-296 fms.), with bottom temperatures of $5.4-5.7^{\circ} \mathrm{C}\left(41.8-42.2^{\circ} \mathrm{F}\right)$.

\section{Remarks}

Myxoderma forms part of a species complex extending down the west coast of North America to Chile (Mah, 2007). As summarized by Mah (2007) Myxoderma frequently occurs on soft bottoms in great abundance when collected.

Myxoderma sacculatum (Fisher, 1905)

Fig. 12C, D

Zoroaster (Myxoderma) sacculatus Fisher, 1905: 316 (“Albatross" St. 4517, off Point Pinos, Monterey Bay, California).

Zoroaster evermanni.- H. L. Clark, 1913: 198.

Myxoderma sacculatum ectenes Fisher, 1919: 392 (key), 392 (text); 1928 a: 45 (key), 49, pl. 14, figs. 4, 4a, 4b, pl. 21, fig. 1, pl. 22, fig. 1, pl. 25, figs. 5-12 (“Albatross” St. 5694, SW of Santa Cruz Island, California); 1930: 200 (list).

Myxoderma sacculatum.- Fisher, 1919: 392 (key); 1928 a: 45 (key), 45 (text), 54, pl. 14, fig. 5, pl. 15, fig. 1, 1a-c, pl. 20, fig. 2, pl. 21, figs. 2, 3, pl. 22, figs. 2, 3, pl. 25, fig. 4; 1930: 200 (list).- H. L. Clark, 1920: 99 (key); 1923: 152.- Alton, 1966: 1709.- Muscat, 1980: 266.- Maluf, 

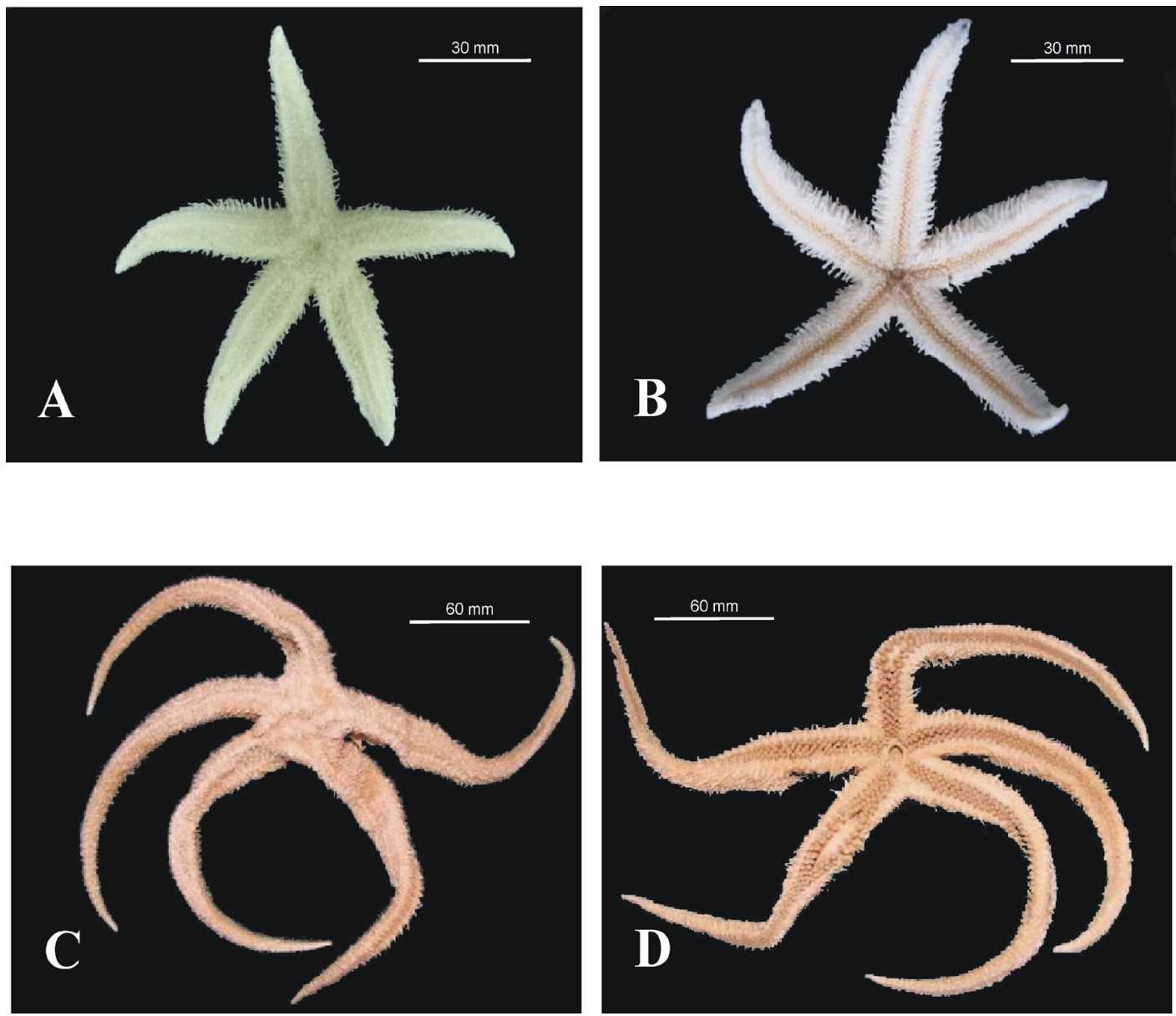

Figure 12. Forcipulatida. A. Myxoderma platyacanthum (H. L. Clark, 1913), aboral view. B. Same, oral view. C. Myxoderma sacculatum (Fisher, 1905), aboral view. D. Same, oral view.

1988: 44 (table), 125 (list).- Mah, 2007: 193.

Myxoderma cf. sacculatum cf. ectenes.- Luke, 1982: 21.

\section{Taxonomic summary}

Material examined. TALUD III, St. 14A (243'소' $\left.108^{\circ} 26^{\prime} 54^{\prime \prime} \mathrm{W}\right), 19 /$ August/1991, one specimen $(\mathrm{R}=$ $118.9 \mathrm{~mm}, \mathrm{r}=14.7 \mathrm{~mm}$ ), Agassiz dredge, 1016-1020 m (EMU-8977).

TALUD III, St. 24A (254'12'N, 109 46'48”'W), 24/ August/1991, one specimen $(\mathrm{R}=156.8 \mathrm{~mm}, \mathrm{r}=32.5 \mathrm{~mm})$, bottom sledge, 1027-1060 m (EMU-8978).

Previous records in Mexico. "Albatross" St. 4380 (32 $\left.26^{\prime} 00^{\prime} \mathrm{N}, 117^{\circ} 18^{\prime} 00^{\prime} \mathrm{W}\right)$, off Los Coronados Islands, Baja California, 970-1131 m (530-618 fms.) (Fisher, 1928a; as M. s. ectenes). Probably the record of $M$. cf. sacculatum cf. ectenes, off Descanso Bay $\left(32^{\circ} 05^{\prime} 12^{\prime}\right.$ 'N, $\left.117^{\circ} 14^{\prime} \mathrm{W}\right)$, Baja California, in depths of 1244-1332 m (Luke, 1982) (Fig. 11B).
Distribution and ecology. The type locality is off Point

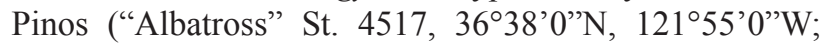
916 fms., ca 1670 m), Monterey, California (Fisher, 1905). Known from Bering Sea, Alaska, USA, to "Tijuana", west coast of Baja California, in depths of 519-1 $936 \mathrm{~m}$ (Maluf, 1988). Present record extends the distribution of M. sacculatum to the Gulf of California, off southern Sinaloa (Fig. 11 B). The material collected during this study (in depths of 1 016-1 $060 \mathrm{~m}$ ) was obtained within the known depth range of this species. Epibenthic temperature and dissolved oxygen concentration: $3.27-4.38^{\circ} \mathrm{C}(37.9-$ $39.9^{\circ} \mathrm{F}$ ) (H. L. Clark, 1913); $0.40 \mathrm{ml} \mathrm{O}_{2} / 1$ (this study).

\section{Remarks}

Based on Fisher 1928(a) Z. evermanni H. L. Clark (1913) from "Albatross" Sts. 5694 to 99 were in error and all correspond to M. sacculatum, in depths of 842-1 190 m (460-650 fms.) (H. L. Clark, 1913). 
Depth distribution of species

Considering all samples of Asteroidea obtained during the TALUD cruises (Table 2), occurrence of species according to depth varies considerably (Table 3). During the survey, gears were operated in a depth range of 377-2 $394 \mathrm{~m}$. Sampling effort was not always successful, however, and a significant number of samples (90 out of a total of 116, or $78 \%$ ) contained no Asteroidea. Six species were obtained in the depth range of $377-750 \mathrm{~m}$, corresponding to a unique sample (in 587-633 $\mathrm{m}$ depth). The 7 additional trawls in that range failed to collect any asteroids. Comparatively,
11 species were captured in the 751-1 $000 \mathrm{~m}$ depth range (11 samples of Asteroidea obtained in 27 trawls), 8 in the $1001-1250 \mathrm{~m}$ range ( 9 samples in 27 trawls), and 4 in the $1251-1500 \mathrm{~m}$ range (3 samples in 18 trawls). Only 1 species was found in deeper water, although the sampling gears sampled 36 times in depths between 1500 -2 394 $\mathrm{m}$. No species covers the entire depth range as defined in Table 3. Ceramaster leptoceramus was collected in the 3 shallowest depth intervals and Nerachaster aciculosus in the 3 deepest intervals (Table 3).

Table 2. Sampling stations of the TALUD cruises where specimens of Asteroidea were collected and list of species per station. Position, depth, and epibenthic water temperature and dissolved oxygen concentration are indicated for each station. Precision of data may vary according to the method used during the survey

\begin{tabular}{|c|c|c|c|c|c|}
\hline Cruise & Station & Species & Depth (m) & $T^{\circ} \mathrm{C}$ & $\mathrm{O}_{2} \mathrm{ml} / \mathrm{l}$ \\
\hline TALUD III & St. 14A & $\begin{array}{l}\text { Dipsacaster laetmophilus } \\
\text { Thrissacanthias penicillatus } \\
\text { Myxoderma sacculatum }\end{array}$ & $1016-1020$ & ND & 0.4 \\
\hline TALUD III & St. $24 \mathrm{~A}$ & $\begin{array}{l}\text { Thrissacanthias penicillatus } \\
\text { Nearchaster aciculosus } \\
\text { Myxoderma sacculatum }\end{array}$ & $1027-1060$ & ND & ND \\
\hline TALUD IV & St. 19 & Pectinaster agassizii & $1240-1245$ & 3.7 & 0.73 \\
\hline TALUD IV & St. 21 & Ctenodiscus crispatus & 1200 & 2.4 & 1.82 \\
\hline TALUD IV & St. 25 & $\begin{array}{c}\text { Radiaster sp. } \\
\text { Ceramaster leptoceramus } \\
\text { Mediaster transfuga } \\
\text { Myxoderma platyacanthum }\end{array}$ & $835-870$ & 5.0 & 0.29 \\
\hline TALUD IV & St. 34 & Pectinaster agassizii & $1240-1250$ & 3.5 & 0.79 \\
\hline TALUD V & St. 11 & $\begin{array}{c}\text { Radiaster } \mathrm{sp} . \\
\text { Mediaster transfuga }\end{array}$ & 860 & 5.4 & 0.07 \\
\hline TALUD V & St. 18 & Ceramaster leptoceramus & $940-990$ & 5.0 & 0.15 \\
\hline TALUD V & St. 19 & $\begin{array}{l}\text { Thrissacanthias penicillatus } \\
\text { Nearchaster aciculosus }\end{array}$ & $1180-1200$ & 4.0 & 0.38 \\
\hline TALUD V & St. 20 & Ctenodiscus crispatus & $1470-1525$ & 2.8 & 1.20 \\
\hline TALUD V & St. 25 & Nearchaster aciculosus & $800-860$ & 5.2 & 0.13 \\
\hline TALUD VI & St. 18 & $\begin{array}{c}\text { Radiaster } \mathrm{sp} . \\
\text { Myxoderma platyacanthum }\end{array}$ & $890-950$ & 5.3 & 0.29 \\
\hline TALUD VII & St. 13B & Nymphaster diomedeae & $1400-1450$ & 3.0 & 1.04 \\
\hline TALUD VIII & St. 3 & Thrissacanthias penicillatus & 1100 & 3.0 & 0.39 \\
\hline TALUD VIII & St. 11 & $\begin{array}{c}\text { Henricia } \text { sp. } 1 \\
\text { Lophaster furcilliger } \\
\text { Ampheraster chiroplus } \\
\text { Anteliaster coscinactis }\end{array}$ & 920 & 5.0 & 0.2 \\
\hline TALUD VIII & St. 16 & $\begin{array}{l}\text { Dipsacaster laetmophilus } \\
\text { Thrissacanthias penicillatus } \\
\text { Ceramaster leptoceramus } \\
\text { Myxoderma platyacanthum }\end{array}$ & 1030 & 5.0 & 0.2 \\
\hline TALUD VIII & St. 20 & Thrissacanthias penicillatus & 1150 & 4.0 & 0.30 \\
\hline
\end{tabular}


Table 2. Continues

\begin{tabular}{|c|c|c|c|c|c|}
\hline Cruise & Station & Species & Depth (m) & $T^{\circ} \mathrm{C}$ & $\mathrm{O}_{2} \mathrm{ml} / \mathrm{l}$ \\
\hline TALUD IX & St. 17 & $\begin{array}{c}\text { Radiaster sp. } \\
\text { Nearchaster aciculosus } \\
\text { Ampheraster hyperonchus } \\
\text { Myxoderma platyacanthum }\end{array}$ & $826-836$ & 5.75 & $<0.05$ \\
\hline TALUD X & St. 4 & $\begin{array}{c}\text { Ceramaster leptoceramus } \\
\text { Henricia } \text { sp. } 1 \\
\text { Henricia } \text { sp. } 2 \\
\text { Lophaster furcilliger } \\
\text { Peribolaster biserialis } \\
\text { Ampheraster hyperonchus }\end{array}$ & $587-633$ & 8.2 & 0.38 \\
\hline TALUD X & St. 5 & $\begin{array}{c}\text { Lophaster furcilliger } \\
\text { Ampheraster hyperonchus } \\
\text { Myxoderma platyacanthum }\end{array}$ & $820-837$ & 6.6 & 0.11 \\
\hline TALUD X & St. 8 & Myxoderma platyacanthum & $975-1007$ & 4.2 & 0.26 \\
\hline TALUD X & St. 10 & $\begin{array}{c}\text { Dipsacaster laetmophilus } \\
\text { Nearchaster aciculosus }\end{array}$ & $1399-1422$ & 3.2 & 0.44 \\
\hline TALUD X & St. 14 & $\begin{array}{c}\text { Radiaster } \mathrm{sp} . \\
\text { Nearchaster aciculosus } \\
\text { Ampheraster hyperonchus }\end{array}$ & $905-943$ & 4.6 & 0.2 \\
\hline TALUD X & St. 18 & Pectinaster agassizii & 1526 & 3.2 & 0.59 \\
\hline TALUD X & St. 25 & $\begin{array}{c}\text { Radiaster } \mathrm{sp} . \\
\text { Nearchaster aciculosus }\end{array}$ & $837-840$ & 5.0 & 0.18 \\
\hline
\end{tabular}

Table 3. Occurrence of deep-water species of Asteroidea collected during the TALUD survey per bathymetric intervals ( 377 to 2250 $\mathrm{m}$ ) in the Gulf of California. Data taken from table 2. Average depths were used for trawls with a minimum and a maximum operating depths (e.g., 1498 m was used for the 1 470-1 525 depth interval). Exterme depth values (bold) correspond to the lowest and deepest trawls during the entire survey. Number of trawls of the survey, of samples with Asteroidea, and of collected species are indicated for comparison purposes

\section{7-750 m}

8 trawls, 1 sample, 6 species

Ceramaster leptoceramus

Henricia sp. 1

Henricia sp. 2

Lophaster furcilliger

Peribolaster biserialis

Ampheraster hyperonchus

751-1 $000 \mathrm{~m}$

27 trawls, 12 samples, 12 species

Radiaster sp.

Nearchaster aciculosus Ampheraster chiroplus Ampheraster hyperonchus

Henricia sp. 1

Lophaster furcilliger

Pectinaster agassizii

Ceramaster leptoceramus

Mediaster transfuga

Anteliaster coscinactis

Myxoderma platyacanthum
$1001-1250 \mathrm{~m}$

27 trawls, 9 samples, 8 species

Dipsacaster laetmophilus

Thrissacanthias penicillatus

Ctenodiscus crispatus

Nearchaster aciculosus

Pectinaster agassizii

Ceramaster leptoceramus

Myxoderma platyacanthum

Myxoderma sacculatum

$1251-1500 \mathrm{~m}$

18 trawls, 3 samples, 4 species

Dipsacaster laetmophilus

Ctenodiscus crispatus

Nearchaster aciculosus

Nymphaster diomedeae

$1501-2250 \mathrm{~m}$

36 trawls, 1 sample, 1 species 


\section{Discussion}

In total, 18 species of Asteroidea were collected in the Gulf of California during the TALUD survey, 15 identified to species-level. The material was obtained in 25 samples. Eleven of these contained only 1 species of Asteroidea, 5 samples contained 2 species, 4 samples 3 or 4 , and 1 sample 6 species (Table 2). Taxonomic affinities of the sampled asteroids show a strong continuity with the deepwater shelf faunas present along the continental shelf of the west coast of North America, as summarized in Fisher (1911b, 1928a, b) and in Maluf (1988).

Recent reviews of Pacific coast Asteroidea in Mexican waters include contributions of Maluf (1988), Maluf and Brusca (2005), Solís-Marín et al. (2005), and HoneyEscandón et al. (2008). Solís-Marín et al. (1997) reviewed shallow-water echinoderms of the Bay of La Paz, but their list does not include deep-water species. Eleven of the 52 species listed by Maluf (1988) were collected during this survey. The other collected species include an undescribed Radiaster, in addition to Dipsacaster letmophilus, which had previously been known only from Alaska; Peribolaster biserialis, previously known only from Alaska to California; Ampheraster chiroplus previously known only from Southern California; and Mediaster transfuga, which had been included in the synonymy of M. tenellus Fisher, 1905 by Maluf (1988). Apart from the identified or new species, additional material includes 2 unidentified species of Henricia. Of the 44 species listed by Maluf (1991) for the Galapagos, 24 have been found below or near $500 \mathrm{~m}$ depth, but only 4 species, i.e., Luidia foliolata (deepest record at $476 \mathrm{~m}$ ), Pectinaser agassizii, Nymphaster diomedeae, and Lophaster furcilliger, occur in Mexican waters. Pawson and Ahearn (2001) reported 10 asteroid species from bathyal depths in the Galapagos, including some range extensions for 2 species occurring in Mexican waters (i.e., Ceramaster grenadensis patagonicus and Cryptopeltaster lepidonotus). Maluf and Brusca (2005) included 63 species of Asteroidea in their checklist of the Gulf of California. Of these, 25 correspond to the deep-water species (see Table 1). In the contributions of Solís et al. (2005) and Honey-Escandón et al. (2008), 10 species with at least 1 record in Mexico are enlisted, 9 present within the Gulf of California and 5 elsewhere (i.e., California Current or SW Mexico).

Not including the unidentified material, a total of 54 records of deep-water Asteroidea were obtained for the Gulf of California during this survey. Comparatively, only 9 records were previously known for this area for the same set of species (compare solid and open symbols on the distribution maps). Ten new distributions records were obtained during this survey for Dipsacaster laetmophilus and Perolobaster biserialis (first record for Mexico), Myxoderma sacculatum, Anteliaster coscinactis, Mediaster transfuga, and Ampheraster chiroplus (to the southern Gulf of California), Ceramaster leptoceramus (first records within the Gulf of California), Ampheraster hyperoncus and Nearchaster aciculosus (to the southern and central Gulf of California), and Lophaster furcilliger (first record within the Gulf of California). With 6 records between ca $24^{\circ} 16^{\prime} \mathrm{N}$ and ca $25^{\circ} 56^{\prime} \mathrm{N}$, the presence of Thrissacanthias penicillatus is confirmed throughout the southern Gulf of California. Myxoderma platyacanthum, reported off Sonora by SolísMarín et al. (2005), is confirmed as a Gulf of California species, well represented in the TALUD samples (6 lots), between ca $24^{\circ} 15^{\prime} \mathrm{N}$ and ca $28^{\circ} 14^{\prime} \mathrm{N}$.

Based on the present study and recent contributions, the number of deep-water $(>500 \mathrm{~m})$ species known to occur off the Pacific coast of Mexico is updated to a grand total of 60 species. Without considering the Mexican record of Anthenea mexicana (no locality available), 34 species have at least 1 record in the California Current area, 41 in the Gulf of California, and only 8 off Southwestern Mexico. Three species have been captured close to offshore islands (Table 1). These figures clearly indicate the lack of sampling activities off SW Mexico.

When compared to the environmental data associated with previous captures of the 15 species identified during this survey, data obtained during the TALUD cruises conform to known records for these species. For example, bathymetric range was within the known depth range of most species. We extended the depth range of Dipsacaster letmophilus, from $1272 \mathrm{~m}$ to $1422 \mathrm{~m}$. The depth range of Myxoderma platyacanthum and of Ampheraster hyperonchus was extended, from 768 to $1030 \mathrm{~m}$ for the former and from $519 \mathrm{~m}$ to $846 \mathrm{~m}$ for the latter, while the depth range for Mediaster transfuga is now set as 789-902 $\mathrm{m}$. Previous data available for bottom temperature (mostly recorded at the "Albatross" sampling stations) are close to those recorded during this study (Table 4). Epibenthic dissolved oxygen concentrations associated with the capture of the specimens show a strong tolerance to severe hypoxia $(<1.0 \mathrm{ml} \mathrm{O} / 1)$ for most species. Ctenodiscus crispatus and Nymphaster diomedeae (Table 3) showed less tolerance and occur in more mildly hypoxic settings. Shick (1976) reported that C. crispatus (at $5^{\circ} \mathrm{C}$ ) can withstand exposure to hypoxia more than any echinoderm known in the literature, but our data indicate that several other species of Asteroidea feature a stronger tolerance to hypoxy than C. crispatus.

The depth interval at which the Asteroidea were collected during this survey (587-1525 m) is much reduced compared to the global depth interval of the entire survey (377 to $2394 \mathrm{~m}$ depth). Only 2 specimens of sea-stars were 
Table 4. Number of specimens collected and number of stations where Asteroidea were found during the TALUD cruises. Environmental data measured at bottom level $\left(\mathrm{T}^{\circ} \mathrm{C}\right.$, temperature; $\mathrm{O}_{2}$, dissolved oxygen concentration) are indicated for previous records and for samples obtained during the TALUD cruises. ND, no data

\begin{tabular}{|c|c|c|c|c|c|}
\hline Species & $\begin{array}{l}\text { Number of } \\
\text { specimens }\end{array}$ & $\begin{array}{c}\text { Number of } \\
\text { stations }\end{array}$ & $T^{\circ} C(T A L U D)$ & $T^{\circ} C$ (Previous) & $\mathrm{O}_{2}(T A L U D)$ \\
\hline Dipsacaster laetmophilus & 5 & 3 & $3.19-5.00$ & ND & $0.20-0.44$ \\
\hline Thrissacanthias penicillatus & 8 & 6 & $3.00-5.00$ & 5.0 & $0.20-0.40$ \\
\hline Ctenodiscus crispatus & 2 & 2 & $2.40-2.80$ & $2.94-3.28$ & $1.20-1.82$ \\
\hline Radiaster sp. nov. & 116 & 6 & $4.64-5.40$ & ND & $0.07-0.29$ \\
\hline Nearchaster aciculosus & 107 & 6 & $3.19-5.75$ & 4.38 & $0.03-0.44$ \\
\hline Pectinaster agassizii & 4 & 3 & $3.17-3.69$ & $2.39-4.11$ & $0.59-0.79$ \\
\hline Ceramaster leptoceramus & 8 & 4 & $5.00-8.22$ & 7.0 & $0.15-0.38$ \\
\hline Mediaster transfuga & 3 & 2 & $5.03-5.40$ & 4.8 & $0.07-0.29$ \\
\hline Nymphaster diomedeae & 3 & 2 & $3.0-3.7$ & $2.89-6.28$ & $0.73-1.04$ \\
\hline Henricia sp. 1 & 8 & 2 & $5.0-8.22$ & ND & $0.2-0.38$ \\
\hline Henricia sp. 2 & 4 & 1 & 8.22 & ND & 0.38 \\
\hline Lophaster furcilliger & 32 & 3 & $5.00-8.22$ & ND & $0.11-0.38$ \\
\hline Peribolaster biserialis & 2 & 1 & 8.22 & ND & $0-38$ \\
\hline Ampheraster chiroplus & 1 & 1 & 5.0 & ND & 0,2 \\
\hline Ampheraster hyperoncus & 17 & 3 & $5.03-8.22$ & 7.0 & $0.03-0.38$ \\
\hline Anteliaster coscinactis & 1 & 1 & 5.0 & 7.0 & 0,2 \\
\hline Myxoderma platyacanthum & 12 & 6 & $4.25-6.65$ & 7.0 & $0.03-0.29$ \\
\hline Myxoderma sacculatum & 2 & 2 & ND & $3.27-4.38$ & 0,4 \\
\hline Total of specimens & 335 & & & & \\
\hline
\end{tabular}

found below $1525 \mathrm{~m}$, but deep-water invertebrates often feature a patchy distribution. The lack of material below that depth, however, cannot be attributed to low frequency of sampling because as many as 36 trawls were at a depth greater that $1500 \mathrm{~m}$ during the survey.

Comparative data related to communities of deep water Asteroidea are lacking for the area between Mexico and northern Peru. In the northwestern part of the American continent, however, there have been several deep water surveys of the megafauna on the continental slope and abyssal plains using both conventional trawls and camera sled. One of the most abundant and diverse collection of deep-water Asteroidea was reported by Alton (1966), off northern Oregon. He reported as many as 54 species, 46 below $460 \mathrm{~m}$ ( $250 \mathrm{fms}$.). Of these, only 9 species were collected during the TALUD survey. In a more recent survey, off central California, Nybakken et al. (1998) report 14 species of Asteroidea captured below 2300 m, none of which were collected during the TALUD survey. Tilot (2006) reported 7 species observed during deepwater dives in the fracture area of Clarion and Clipperton with only 1 species, Pectinaster agassizii, collected during the TALUD cruises. Keller et al. (2007) reported 53 species (some unidentified) of Asteroidea off the coast of California to Washington, 51 with at least 1 specimen below $300 \mathrm{~m}$ depth. Of these, 7 were found during the TALUD survey.
Asteroid specimens were found in only 25 of the 116 samples taken during this survey. This is certainly significant, and indicates that species distribution is far from being homogeneous. Species richness was low, and only 9 samples contained 3 of more species (maximum of 6; St. 4, TALUD X). Due to lack of additional sampling effort, however, it is difficult to explain the distribution patterns of these species. Factors such as patterns of deepwater currents and species dispersion, food supply and bottom structure can have an additional effect on depth, temperature and dissolved oxygen concentration.

\section{Acknowledgments}

The authors thank the scientists, students and crew members who participated in the TALUD cruises aboard the R/V "El Puma". One of us (MEH) is grateful to the Royal Belgian Institute of Natural Sciences (RBINS) and the Free University of Brussels (ULB) for their hospitality during his sabbatical leave. Special thanks to Thierry Backeljau (RBINS), Michel Jangoux (ULB) for their invitation and to Frank Fiers, Claude Massin, Philippe Willenz (RBINS), and Chantal De Ridder (ULB), for the facilities provided. Permanent access to literature available in the Laboratoire de Biologie Marine, ULB, was particularly helpful. The DGAPA, PASPA, UNAM, Mexico, is acknowledged for providing support during MEH sabbatical stay. $\mathrm{CMZ}$ 
was supported with a CONACyT Master Degree grant (216056). We thank Gordon Hendler for providing data related to the Allan Hancock expeditions material, the 2 anonymous reviewers for their helpful suggestions, and Mercedes Cordero for preparation of maps and final edition of the manuscript. This project was partly supported by CONACyT, Mexico (project 31805-N) and DGAPA (project IN-217306-3), UNAM, Mexico.

\section{Literature cited}

Alton, M. S. 1966. Bathymetric distribution of sea stars (Asteroidea) off the northern Oregon coast. Journal of the Fisheries Research Board of Canada 23:1673-1714.

Baranova Z. I. 1957. [Echinoderms of the Bering Sea] Issledovaniya Dalny-Vostok Morei USSR 4:149-266. (In Russian).

Blake, D. B. 1973. Ossicle morphology of some recent asteroids and description of some West American fossil asteroids. University of California Publications in Geological Sciences 104:1-59.

Blake, D. B. 1987. A classification and phylogeny of postPaleozoic sea stars (Asteroidea: Echinodermata). Journal of Natural History 21:481-528.

Borowski, C. 2001. Physically disturbed deep-sea macrofauna in the Peru Basin, southeast Pacific, revisited 7 years after the experimental impact. Deep Sea Research 48:3809-3839.

Carey, A. G. 1972. Food sources of sublittoral, bathyal, and abyssal asteroids in the Northeast Pacific Ocean. Ophelia 10:35-47.

Clark, A. H. 1916. Six new starfishes from the Gulf of California and adjacent waters. Proceedings of the Biological Society of Washington 29:51-62.

Clark, A. M. 1989. An index of names of recent Asteroidea. Part 1: Paxillosida and Notomyotida, in Jangoux, M. and Lawrence, J.M. (eds.). Echinoderms Studies. A.A. Balkema, Roterdam, Brookfield. 225-347.

Clark, A. M. 1993. An index of names of recent Asteroidea. Part 2. Valvatida. In Echinoderm Studies, M. Jangoux and J. M. Lawrence (eds.). A. A. Balkema, Rotterdam. p. 187-366.

Clark, A. M. 1996. An index of names of recent Asteroidea. Part 3. Velatida and Spinulosida. In Echinoderm Studies, M. Jangoux and J. M. Lawrence (eds.). A. A. Balkema, Rotterdam. p. 183-250.

Clark, A. M. and M. E. Downey. 1992. Starfishes of the Atlantic. Natural History Museum Publications. Identification Guide 3. Chapman and Hall, London. U.K. 799 p.

Clark, A. M. and C. Mah. 2001. An index of names of recent Asteroidea, Part 4: Forcipulatida and Brisingida. Echinoderm Studies 6:229-347.

Clark, H. L. 1913. Echinoderms from Lower California, with descriptions of new species. Bulletin of the American
Museum of Natural History 32:185-236, 3 plates.

Clark, H. L. 1920. Reports on the scientific results of the expedition to the Eastern Tropical Pacific, in charge of Alexander Agassiz, by the U.S. Fish Commission Steamer "Albatross", from October, 1904, to March, 1905, Lieut. Commander L.M. Garrett, U.S.N., commanding, XXXII: Asteroidea. Memoirs of the Museum of Comparative Zoology at Harvard College 39:75-113, 6 plates.

Clark, H. L. 1923. Echinoderms from Lower California, with descriptions of new species: supplementary report. Bulletin of the American Museum of Natural History 48:147-163.

Djakonov A. M. 1950. [Starfish of the Soviet Union]. Tabl. Anal. Faune URSS 34: 1-203. [Translated as Dyakonov. A.M. 1968. Sea stars (Asteroids) of the USSR Seas. Keys to the Fauna of the USSR 34. Zoological Institute of the Academy of Sciences of the USSR, A. A. Strelkov (ed.). Israel Program for scientific translations Ltd. Jerusalem, 183 p.]

Fisher, W. K. 1905. New starfishes from deep water off California and Alaska. Bulletin of the Bureau of Fisheries for 1904, 29:291-320.

Fisher, W. K. 1906a. New starfishes from the Pacific coast of North America. Proceedings of the Washington Academy of Sciences 8:111-139.

Fisher, W. K. 1906b. Two new starfishes from Monterey Bay, California. Zoologischer Anzeiger 30:299-302.

Fisher, W. K. 1910a. XXIII. New Pterasteridae from the North Pacific. Annals and Magazine of Natural History ser. 8, 5:167-173.

Fisher, W. K. 1910b. New Starfishes from the North Pacific, I: Phanerozonia. Zoologischer Anzeiger 35:545-553.

Fisher, W. K. 1910c. New starfishes from the North Pacific, II: Spinulosa. Zoologischer Anzeiger 35:568-574.

Fisher, W. K. 1911a. Two new genera of starfishes. Annals and Magazine of Natural History ser. 8, 7:89-92.

Fisher, W. K. 1911b. Asteroidea of the North Pacific and adjacent waters, Part I: Phanerozonia and Spinulosa Bulletin of the United States National Museum 76:1-419, 122 plates.

Fisher, W. K. 1917. New genera and species of Brisingidae. Annals and Magazine of Natural History ser. 8, 20:418-431.

Fisher, W. K. 1919. On North Pacific Zoroasteridae. Annals and Magazine of Natural History ser. 9, 3:387-393.

Fisher, W. K. 1923. A Preliminary Synopsis of the Asteriidae, a Family of Seastars. Annals and Magazine of Natural History ser. 9, 12:247-258.

Fisher, W. K. 1928a. Asteroidea of the North Pacific and adjacent waters, Part 2: Forcipulata (Part). Bulletin of the United States National Museum 76:1-245, 81 plates.

Fisher, W. K. 1928b. Sea stars from the Arcturus Oceanographic Expedition. Zoologica, N.Y. 8:487-493.

Fisher, W. K. 1930. Asteroidea of the North Pacific and adjacent waters. Part 3. Forcipulatida (concluded). Bulletin of the 
United States National Museum 76:1-356, 93 plates.

Grassle, J. F. 1989. Species diversity in deep-sea communities. Trends in Ecology and Evolution 4:12-15.

Hendrickx, M. E. 2001. Occurrence of a continental slope decapod crustacean community along the edge of the minimum oxygen zone in the southeastern Gulf of California, Mexico. Belgian Journal of Zoology 131:95-109.

Hendrickx, M. E. and J. Salgado-Barragán. 1991. Los estomatópodos (Crustacea: Hoplocarida) del Pacífico mexicano. Publicación Especial Instituto de Ciencias del Mar y Limnología, Universidad Nacional Autónoma de México 10:1-200.

Hendrickx, M. E. and D. Serrano. 2010. Impacto de la zona de mínimo de oxígeno sobre los corredores pesqueros en el Pacífico mexicano. Interciencia 35:12-18.

Honey-Escandón, M., F. A. Solís-Marín and A. LaguardaFigueras. 2008. Equinodermos (Echinodermata) del Pacífico Mexicano. Revista de Biología Tropical 56 (Suppl. 3):57-73.

Keller, A. A., V. H. Simon, B. H. Homess, J. R. Wallace, V. J. Tuttle, E. L. Fruh, K. L. Bosley, D. M. Kamikawa and J. C. Buchanan. 2007. The 2003 U.S. West Coast bottom trawl survey of ground fish resources off Washington, Oregon, and California: Estimates of distribution, abundance, and length composition. U.S. Department of Commerce, NOAA Technical Memoir NMFS-NWFSC-86. 130 p.

Kröncke, I. and M. Türkay. 2003. Structural and functional aspects of the benthic communities in the deep Angola basin. Marine Ecology Progress Series 260:43-53.

Lambert, P. 2000. Sea Stars of British Columbia, Southeast Alaska, and Puget Sound. Royal British Columbia Museum Handbook. UBC Press, Vancouver, BC. 186 p.

Levin, L. A. and J. D. Gage. 1998. Relationships between oxygen, organic matter and the diversity of bathyal macrofauna. Deep-Sea Research II 45:129-163.

Levin, L. A., R. J. Etter, M. A. Rex, A. J. Gooday, C. R. Smith, J. Pineda, C. T. Stuart, R.R. Hessler and D. Pawson. 2001. Environmental influences on regional deep-sea species diversity. Annual Review Ecology System 32:51-93.

Luke, S. R. 1982. Catalog of the Benthic Invertebrate Collections, Echinodermata. Scripps Institution of Oceanography Reference Series, No. 82-5. University of California. $71 \mathrm{p}$.

Ludwig, H. 1905. Asteroidea. In Reports on an exploration off the west coasts of Mexico, Central and South America, and off the Galapagos Islands, in charge of Alexander Agassiz, by the U.S. Fish Commission Steamer "Albatross", during 1891, Lieut. Commander ZL. Tanner, U.S.N., commanding and reports on the scientific results of the expedition to the Tropical Pacific, in charge of Alexander Agassiz, on the U.S. Fish Commission Steamer "Albatross", from August, 1899, to March, 1900, Commander Jefferson F. Moser, U.S.N.
Commanding. Memoirs of the Museum of Comparative Zoology at Harvard College 32:1-292, 35 plates, 1 chart

Ludwig, H. 1907. Diagnose neuer Tiefsee-Seesterne aus der Familie der Porcellanasteriden. Zoologische Anzeiger 31:312-319.

Ludwig, H. 1910. Notomyota, eine Neue Ordnung der Seesterne. Sitzung Königliche. Preussischen Akademie Wissenschaften, 23:435-466.

Madsen, F. J. 1956. Reports of the Lunds University Chile Expedition 1948-49, 24, Asteroidea, with a survey of the Asteroidea of the Chilean shelf. Acta University of Lunds (N.S.) 52:1-53.

Mah, C. 2007. Phylogeny of the Zoroasteridae (Zorocallina; Forcipulatida): evolutionary events in deep-sea Asteroidea displaying Palaeozoic features. Zoological Journal of the Linnean Society 150:177-210.

Maluf, L. Y. 1988. Composition and distribution of the Central Eastern Pacific echinoderms. Technical Report, Natural History Museum of Los Angeles County 2:1-242.

Maluf, L. Y. 1991. Echinoderm Fauna of the Galapagos Islands. Chapter 16. In Galapagos Marine Invertebrates: Taxonomy, Biogeography and Evolution in Darwin's Islands, M. J. James (ed.). Plenum Press, New York p. 345-367.

Maluf, L. I. and R. C. Brusca. 2005. Echinodermata. Chapter 18. In A Distributional checklist of the macrofauna of the Gulf of California, Mexico. Part I. Invertebrates. [Listado y distribución de la macrofauna del golfo de California, México, Parte I. Invertebrados], M. E. Hendrickx, R. C. Brusca and L. T. Findley (eds.). Arizona-Sonora Desert Museum, Tucson, Az. USA p. 327-343.

McClain, C. R. 2004. Connecting species richness, abundance and body size in deep-sea gastropods. Global Ecology and Biogeography 13:327-334.

McClain, C. R. and M. A. Rex. 2001. The relationship between dissolved oxygen concentration and maximum size in deepsea turrid gastropods: an application of quantile regression. Marine Biology 139: 681-685.

Méndez, N. 2006. Deep-water polychaetes (Annelida) from the southeastern Gulf of California, Mexico. Revista de Biología Tropical 54:773-785.

Muscat, A. M. 1980. Echinodermata (excludes Holothuroidea). In A taxonomic listing of common marine invertebrate species from Southern California, D. Straugham and R. W. Klink (eds.). Technical Reports of the Allan Hancock Foundation 3:263-273.

Nybakken, J., S. Craig, L. Smith-Beasley, G. Moreno, A. Summers and L. Weetman. 1998. Distribution density and relative abundance of benthic invertebrate megafauna from three sites at the base of the continental slope off central California as determined by camera sled and beam trawl. Deep Sea Research II 45:1753-1780.

Pawson, D. L. and C. A. Ahearn. 2001. Bathyal echinoderms of 
the Galapagos Islands. In Echinoderms 2000: Proceedings of the 10th International Conference, Dunedin, New Zealand, 31 January-4 February 2000, M. Barker (ed.). A. A. Balkema. p. 41-46.

Retzius, A. J. 1805. Dissertatio sistens species cognitas Asteriarum. Lundae. 37 p.

Rex, M. A., C. T. Stuart and G. Coyne. 2000. Latitudinal gradients of species richness in the deep-sea benthos of the North Atlantic. Proceedings of the National Academy of Sciences USA 97:4082-4085.

Reynolds, P. D. 2002. The Scaphopoda. In Molluscan radiationlesser know branches, A. J. Southward, P. A. Tyler, C. M. Young and L. A. Fuima (eds.). Advances in Marine Biology 42:137-236.

Rogers, A. D. 2000.The role of oceanic oxygen minimum zones in generating biodiversity in the deep sea. Deep-Sea Research 47:119-148.

Schick, J. M. 1976. Physiological and behavioural responses to hypoxia and hydrogen sulphide in the infaunal asteroid Ctenodiscus crispatus. Marine Biology 37:279-289.

Schick, J. M., K. C. Edwards and J. H. Dearborn. 1981. Physiological ecology of the deposit-feeding sea star Ctenodiscus crispatus: ciliated surfaces and animalsediment interactions. Marine Ecology Progress Series 5:165-184.

Sladen, W. P. 1883. The Asteroidea of H.M.S. Challenger Expedition (Preliminary Notices). 2. Astropectinidae. Journal of the Linnean Society of London, Zoology 17:214-269.

Sladen, W. P. 1889. Asteroidea. Report of the Scientific Results of the Voyage of H.M.S. Challenger 1873-76. 30:1-893, 117 plates.

Smith, C. R., L. A. Levin and S. Mullineaux. 1998. Deepsea biodiversity: a tribute to Robert R. Hessler. Deep-Sea Research II 45:1-11.

Solís-Marín, F. A., H. Reyes-Bonilla, M. D. Herrero-Pérezrul, O. Arizpe-Covarrubias and A. Laguarda-Figueras. 1997. Sistemática y distribución de los equinodermos de la bahía de La Paz. Ciencias Marinas 23:249-263.

Solís-Marín, F. A., A. Laguarda-Figueras, A. Durán-González, C. Gust Ahearn and J. Torres-Vega. 2005. Echinoderms (Echinodermata) from the Gulf of California, Mexico. Revista de Biología Tropical 53 (suppl. 3):123-137.

Tilot, V. 2006. Biodiversité et distribution de la mégafaune. Vol. 2. Atlas photographique annoté des échinodermes de la zone de fractures de Clarion et de Clipperton. Paris, UNESCO/IOC. IOC Tecnhical Series 69:1-62.

Zamorano, P., M. E. Hendrickx and A. Toledano Granados. 2006. Distribution and ecology of deep-water mollusks from the continental slope, southeastern Gulf of California, Mexico. Marine Biology 150:883-892.

Ziesenhenne, F. C. 1937. The Templeton Crocker Expedition. $\mathrm{X}$. Echinoderms from the west coast of Lower California, the Gulf of California and Clarion Island. Zoologica, N.Y. 22:209-239. 